Article

\title{
Improving Fungal Decay Resistance of Less Durable Sapwood by Impregnation with Scots Pine Knotwood and Black Locust Heartwood Hydrophilic Extractives with Antifungal or Antioxidant Properties
}

\author{
Viljem Vek *, Angela Balzano@, Ida Poljanšek, Miha Humar@ and Primož Oven * \\ Department of Wood Science and Technology, Biotechnical Faculty, University of Ljubljana, Jamnikarjeva 101, \\ 1000 Ljubljana, Slovenia; angela.balzano@bf.uni-lj.si (A.B.); ida.poljansek@bf.uni-lj.si (I.P.); \\ miha.humar@bf.uni-lj.si (M.H.) \\ * Correspondence: viljem.vek@bf.uni-lj.si (V.V.); primoz.oven@bf.uni-lj.si (P.O.); Tel.: +386-1-320-3616
}

Received: 13 August 2020; Accepted: 16 September 2020; Published: 22 September 2020

check for updates

\begin{abstract}
Research Highlights: The antifungal assay confirmed that knotwood extractives of Scots pine inhibit the growth of wood decay fungi. Heartwood extracts of black locust were found to be much stronger free radical scavengers than the extracts of Scots pine. The extracts were deposited in the lumina and on the wall surface of cells in the impregnated sapwood. Impregnation of the sapwood blocks with Scots pine and black locust extracts reduced the fungal decay of wood. Objectives: Hydrophilic extracts of Scots pine knotwood and black locust heartwood were chemically analyzed, tested for antifungal and antioxidant properties and used for impregnation of beech and Scots pine sapwood. Materials and Methods: Scots pine knotwood and black locust heartwood were extracted, and obtained hydrophilic extractives were chemically analyzed. Extracts were analyzed for antifungal properties with the in vitro well-diffusion method. The free radical scavenging activity of wood extracts was measured colorimetrically. The retention of the extracts in the impregnated sapwood blocks was evaluated with microscopy and gravimetry. A decay test was performed with the mini block test. Results: Almost half of both Scots pine knotwood and black locust heartwood hydrophilic extracts obtained were described by phenolic compounds. The extracts were deposited in the lumina of cells and on the cell wall surface. Extractives of Scots pine knotwood had good inhibitory properties against white- and brown-rot fungi. On the other hand, extractives of black locust heartwood were found to be good radical scavengers, better than knotwood extractives of Scots pine. The extracts of Scots pine knotwood and black locust reduced the fungal decay of the tested sapwood blocks. Conclusions: The results of this research show that the less-valued knotwood of Scots pine and heartwood of black locust are a potential source of antifungal and antioxidant agents for bio-based wood preservatives.
\end{abstract}

Keywords: Pinus sylvestris; Robinia pseudoacacia; hydrophilic extractives; wood impregnation; fungal growth inhibition; radical scavenging activity; decay resistance

\section{Introduction}

Wood is a source of phytochemicals, also called extractives, which do not combine with structural components of the cell wall and can therefore be removed with polar and nonpolar solvents $[1,2]$. Wood is a renewable and sustainable polymer composite with several unique properties [3], among which, (bio)degradability is considered to be an advantage in biorefining [4,5], for instance, or a disadvantage in applications in which wood is exposed to unfavorable microenvironmental conditions [6]. The biodegradation of wood can be prevented with construction protection [7] and 
thermal and chemical modification [8] by introducing chemicals either via surface protection [9] or impregnation [10,11] or by using more durable woods if available [12]. Formulations for wood preservation currently available for commercial applications are based on copper, with an organic co-biocide added to control copper-tolerant fungi $[13,14]$. They are considered to be emerging pollutants, and an effort is being made to replace them with environmentally more benign agents. The production of eco-friendly protective agents from plant biomasses has received renewed interest in recent years [2,15-20]. Here, we studied the use of biologically active phytochemicals from Scots pine knotwood and from durable black locust heartwood to protect susceptible woods against fungal decay.

The knotwood of pines, generally treated as a residue in the wood-processing industry, has been shown to be a potential source of pinosylvins [21,22]. Both pinosylvins and crude extracts of Scots pine heartwood and knotwood have been comprehensively studied, and it has been reported that these phytochemicals possess antifungal, antimicrobial and antioxidant properties [23-28]. It has been demonstrated that the amount of extractives and the concentration of pinosylvins have a significant influence on the decay resistance of Scots pine heartwood against brown-rot fungus Coniophora puteana [29,30]. Celimene et al. [31] isolated pinosylvins from the n-hexane crude extract of bark, cones or sapwood of white spruce (Picea glauca), jack pine (Pinus banksiana) and red pine (Pinus resinosa), viz., conifer species native to North America. Purified pinosylvin, pinosylvin monomethyl ether and pinosylvin dimethyl ether (provided by the methylation of pinosylvin monomethyl ether and purification) and a mixture of pinosylvins were tested with an antifungal assay on agar. The obtained pinosylvins were also used for the impregnation of wood blocks of red maple and southern yellow pine [31]. The antifungal performances of the solutions were tested on white-rot (Trametes versicolor and Phanerochaete chrysosporium) and brown-rot fungi (Neolentinus lepideus, Gloeophyllum trabeum and Postia placenta). The antifungal assay on agar showed that solutions of pinosylvins inhibited the growth of white-rot fungi and slightly stimulated the growth of brown-rot fungi. In contrast to the results of the antifungal assay on agar, the soil-block bottle assay did not show any significant decay resistance of the pinosylvin-impregnated wood of red maple to white-rot fungi, while the impregnated wood of southern yellow pine showed decay resistance against brown-rot fungi [31]. Similar findings were reported by Wijayanto et al. [32] for Soxhlet-extracted compounds of Sumatran pine (Pinus merkusii), a pine species native to Southeast Asia. The results of the chemical analysis, the 2,2-diphenyl-1-picrylhydrazyl (DPPH) scavenging activity test and the plate assay showed that heartwood and knotwood extractives provide radical scavenging activity and inhibition activity against white-rot fungus Trametes versicolor and brown-rot fungus Poria placenta. A decay assay was not performed. It has been reported that lignans, stilbenes and resin acids of knotwood act more as antioxidants, while many stilbenes in heartwood exhibit antifungal activities [32]. Lu, Venalainen, Julkunen-Tiitto and Harju [28] tested pinosylvins and crude extracts of Scots pine heartwood on three brown-rot fungi: Coniophora puteana, Gloeophyllum trabeum and Rhodonia (Poria) placenta. Before the decay test against brown-rot fungi, sapwood blocks were impregnated first by treatment in a vacuum and then immersed into stilbene-ethanol extracts of Scots pine heartwood [28]. The authors concluded that naturally degradable stilbenes might be applied as wood preservatives only in in-service situations with low or transient risks of decay [28]. A comprehensive study was performed by Seppänen et al. [33], who tested pure pinosylvins with both a malt agar plate test and decay tests with impregnated birch and aspen wood blocks on numerous wood-destroying fungi, including 12 white-rot fungi (Trametes versicolor, Stereum hirsutum, Chondrostereum purpureum, Inonotus obliquus, Fomes fomentarius, Pycnoporus cinnabarinus, Cerrena unicolor, Bjerkandera adusta, Phellinus igniarius, Heterobasidion annosum, Phellinus pini and Phellinus tremulae) and two brown-rot fungi (Piptoporus betulinus and Fomitopsis pinicola). The pinosylvins reduced the decay of impregnated wood blocks significantly. Unlike the plate test, the decay test showed the greater sensitivity of brown-rot fungi to pinosylvins compared to white-rot fungi [33]. These findings confirm the results reported by Celimene, Micales, Ferge and Young [31]. 
On the other hand, durable woods of less-utilized tree species could also be a source of extraction of natural bioactive agents. Black locust is an alien and invasive tree species that is well-distributed in certain parts of Europe [34,35]. The heartwood of black locust is characterized by its high natural durability, but it is still most frequently used as "low-value" wood in vineyards and orchards, although it is also used as material in external flooring applications [34,36]. Less literature data is available on black locust wood extractives and their anti-decay properties. Triterpenes and simple sugars (e.g., sucrose, glucose and fructose) and nonstructural carbohydrates (starch); soluble proteins and phenolic compounds such as simple phenols, phenolic acids, stilbenes, flavonoids and condensed tannins have been identified in the tissues of black locust [37-42]. Flavonoids dihydrorobinetin (flavanonol), robinetin (flavonol) and derivates of hydroxycinnamic acid have been reported to be the characteristic phenolics compounds present in the hydrophilic extracts of black locust heartwood [38,42,43]. The high natural durability of the heartwood of black locust is frequently explained by the presence of bioactive phenolic extractives $[40,41,44]$. It has been demonstrated that the decay resistance of normally nondurable wood can be improved after impregnation with extracts of black locust. Smith, Campbell, Walker and Hanover [44] impregnated aspen wafers by soaking them in a methanol solution containing the combined extracts of black locust heartwood (including hexane, ethyl acetate, methanol and aqueous acetone extracts). The authors found that the combined extracts increased the decay resistance of aspen wood against brown-rot fungus Gloeophyllum trabeum [44]. Sablik et al. [45] reported that the impregnation of sapwood of common beech with $50 \%$ methanol extract of black locust heartwood $(\mathrm{aq}, v / v)$ in a vacuum without an overpressure phase can increase the natural durability of beechwood samples against the white-rot fungus Trametes versicolor. Comprehensive work on the chemistry and possible applications of black locust extractives has been also done by Rademacher et al. [46]. Hosseinihashemi et al. [47] demonstrated that acetone extractives of black locust heartwood exhibited relatively low inhibition activity against white-rot Trametes versicolor; on the other hand, heartwood extractives have been shown to be good 2,2-diphenyl-1-picrylhydrazyl (DPPH) radical scavengers. It has been reported that extractives may protect heartwood wood through fungicidal properties and possibly other nonbiocidal properties, such as free radical scavenging ability, i.e., antioxidants [48].

As already demonstrated by up-to-date findings, antifungal activity measured with antifungal tests on agar cannot fully represent the decay resistance capability [23,49-52]. So, if the phytochemical of interest does not show antifungal activity on agar, that does not mean that it is not capable of inhibiting the fungal decay of wood. Schultz and Nicholas [48] reported that extractives in highly durable heartwood have very poor fungicidal activities compared to commercial biocides. It is therefore important that a bio-based preservative contains natural compounds with different bioactive properties to provide sufficient bioactive performances. The literature provides much interesting information on the antifungal efficiency of extractives of both Scots pine and black locust. The reports include either pure compounds [31,33], crude extracts or even fractions [28,45,47]. Testing on pines has also been done with extracts from wood materials of various pine species [28,31,32]. Different impregnation approaches have been reported. Less durable wood has been reported to have been impregnated with wood extractives of Scots pine and black locust in a vacuum [31,33,45], with two-phase impregnation using a vacuum and immersing [28] or soaking the wood in treating solutions [44]. A literature research revealed that information on the retention of extractives and their distribution in an impregnated wood matrix remains fragmentary. All the research reports mentioned indicate that the results on the antifungal efficiency of pine and black locust are actually ambiguous and do not give clear information due to differences in experimental approaches and tests employed.

The aims of the present investigation were therefore to provide a holistic study on antifungal, anti-decay and antioxidant activities of hydrophilic extractives of Scots pine and black locust. Only woody biomasses of forestry debris and less-utilized tree species usually having low market values were thus selected for extraction. The specific goals were (a) to use the knotwood of broken trees and/or heartwood of commercially less interesting tree species for the extraction and analysis of phytochemicals; (b) to use the obtained hydrophilic extractives for the preparation of aqueous treating 
solutions for wood preservation; (c) to impregnate the less durable sapwood of selected conifers and deciduous tree species and retain the extracts in the wood matrix with a two-phase impregnation process that consisted of a vacuum phase and a high-pressure phase; (d) to examine the retention and deposition of the extracts in impregnated wood using gravimetry and microscopy and (e) to perform a series of tests, including in vitro antifungal assay on agar, in vitro decay test on wood blocks and antioxidant test with measuring the radical scavenging activity. Wood-decaying fungi that frequently attack physiologically weakened standing and dead trees were selected, as well as wooden elements in outdoor use and as construction timber. Schizophyllum commune and Fibroporia vaillantii have also been reported to be resistant to several commercial biocides with semidurable wood [53-56].

\section{Materials and Methods}

\subsection{Chemicals}

Methanol and ethanol (high-performance liquid chromatography (HPLC) grade), formic acid (for LC/MS, 99\%), Folin-Ciocalteu phenol reagent $(2 \mathrm{~N})$, anhydrous sodium carbonate $(99 \%)$, gallic acid monohydrate (HPLC assay, $\geq 99 \%$ ), gallic acid (certified reference material), L-ascorbic acid (reagent grade), butylated hydroxyanisole (analytical reference material) and 2,2-diphenyl-1-picrylhydrazyl (DPPH) were purchased from Merck (Sigma-Aldrich Chemie, Taufkirchen, Germany). Water and acetone, both HPLC grade, were from J.T. Baker (Phillipsburg, NJ, USA). Cyclohexane (99\%), ethyl acetate and dimethylsulphoxide were provided by Carlo Erba Reagents (Chaussée du Vexin, France). All the reference compounds used for chromatographic analysis were obtained from a commercial source. Pinosylvin (HPLC, $\geq 97 \%$ ), pinosylvin monomethyl ether (HPLC, $\geq 97 \%$ ), pinostilbene hydrate (HPLC, $\geq 95 \%$ ), pterostilbene (HPLC, $\geq 97 \%$ ), nortrachelogenin (HPLC, $\geq 95 \%$ ), pinobanksin (HPLC, $\geq 95 \%$ ), pinocembrin (HPLC, $\geq 95 \%$ ) and gallic acid monohydrate (HPLC, $\geq 98.0 \%$ ) were from Merck (Sigma-Aldrich Chemie, Taufkirchen, Germany). Analytical standards robinetin (HPLC assay, $\geq 95 \%$ ) and dihydrorobinetin (HPLC assay, $\geq 99 \%$ ) were supplied by Extrasynthese (Genay, France). Pure pinosylvin (PS) and pinosylvin monomethyl ether (PSMME) used in the in vitro antifungal assay were isolated from the acetone extract of Scots pine knotwood by the method described by Poljanšek et al. [21]. Pure dihydrorobinetin (DHR) and robinetin (Rob) used for the antifungal assay were purchased from Extrasynthese (Genay, France).

\subsection{Material}

Wood of Scots pine (Pinus sylvestris L.) and black locust (Robinia pseudoacacia L.) were included in the present investigation. The materials used in this investigation have already been described in our recent research reports $[57,58]$. Briefly, six Scots pine trees were felled in a Rožnik urban forest $\left(46^{\circ} 03^{\prime} 31.3^{\prime \prime} \mathrm{N} 14^{\circ} 29^{\prime} 32.1^{\prime \prime} \mathrm{E}\right)$ on 8 April 2014, and six black locust trees in a Panovec urban forest $\left(45^{\circ} 56^{\prime} 46.8^{\prime \prime} \mathrm{N} 13^{\circ} 40^{\prime} 05.1^{\prime \prime} \mathrm{E}\right)$ on 26 January 2016. A number of stem discs were taken at different heights of the stems and transported to a woodworking workshop. Knotwood (or simply knots) of Scots pine and heartwood of black locust were selected as material for extraction for the purposes of this study. Selected tissues were then carefully isolated from the stem disc using a band saw and chisel. Discs taken from the lower part of Scots pine trees contained mostly dead knots, while upper parts contained living knots. Since we tried to simulate a larger-scale sampling for industrial purposes, knots were not separated into knotwood of living and dead branches. Twenty-four knots of the six Scots pine trees were prepared for extraction. Heartwood of black locust was sampled across the sample discs in a radial series. For this investigation, 48 heartwood samples of black locust were selected and prepared for extraction. Collected knotwood and heartwood samples were dried overnight at $50{ }^{\circ} \mathrm{C}$ and then ground with a Retsch SM 2000 cutting mill using a 1-mm-bottom sieve. The ground wood was placed in sealed bottles and stored at $-25^{\circ} \mathrm{C}$ until further analysis. 


\subsection{Extraction}

Powders of Scots pine knotwood and black locust heartwood were freeze-dried in a Telstar LyoQuest lyophylizator at $0.040 \mathrm{mbar}$ and $-82^{\circ} \mathrm{C}$. The samples were extracted in a Soxhlet apparatus for $6 \mathrm{~h}$ at $110^{\circ} \mathrm{C}$. Prior to the extraction with acetone, Scots pine knotwood was extracted with cyclohexane in order to remove lipophilic and resinous matter from the knotwood samples. Acetone was used as a solvent for the extraction of hydrophilic extractives from the samples of both species. Scots pine knotwood was extracted with 95\% acetone (aq, v/v) [59], while 90\% acetone (aq, $v / v$ ) was used for the extraction of heartwood samples of black locust [60]. The acetone extractives of Scots pine and black locust were later used for the preparation of water-based preservative solutions. This meant that only hydrophilic extractives were used for antifungal, antioxidant and decay testing. For sufficient amounts of the hydrophilic extracts for the preparation of the treating solutions, each of the 72 samples was extracted two to three times. The obtained extracts were stored in the dark at $-25{ }^{\circ} \mathrm{C}$ until further analysis with gravimetry, spectrophotometry and chromatography. After the chemical analysis, all the acetone extracts were combined and the mass aliquots were mixed separately for Scots pine knotwood and black locust heartwood. Two homogenized hydrophilic extracts were thus prepared, i.e., hydrophilic knotwood extract of Scots pine (KWE) and hydrophilic heartwood extract of black locust (HWE). KWE and HWE were freeze-dried in a lyophylizator as described above and stored in the dark at $-24{ }^{\circ} \mathrm{C}$.

\subsection{Chemical Analysis of Extractives}

The focus here was hydrophilic extractives. All the obtained acetone extracts were qualitatively and quantitatively evaluated for hydrophilic extractives by gravimetry, spectrophotometry and chromatography in order to get information on the amount of total hydrophilic extractives, total phenols and targeted stilbenes and flavonoids. As already mentioned, after the chemical analysis, the extracts were homogenized into KWE and HWE, as described above.

The protocol for the chemical analysis of wood extractives that was applied in this investigation was already described [61,62], and it is briefly summarized below. For assessment of the content of total hydrophilic extractives that were gained from knotwood and heartwood samples, $10 \mathrm{~mL}$ of each acetone extract was oven-dried at $105^{\circ} \mathrm{C}$ to a constant mass.

For the determination of total phenols in extracts, a diluted 2N Folin-Ciocalteu's phenol reagent (aq) and an aqueous solution of sodium carbonate $(75 \mathrm{~g} / \mathrm{L})$ were added to each of the wood extracts $[63,64]$. After two hours incubation of the reaction mixtures, the absorbance was measured at $765 \mathrm{~nm}$. The content of total phenols was expressed in gallic acid mass equivalents (mg GAE).

For a quality check of extracts with HPLC (high-performance liquid chromatography), all individual knotwood and heartwood extracts, as well as homogenized KWE and HWE, were redissolved and diluted in methanol (HPLC grade) and filtered through a $0.22-\mu \mathrm{m}$ polyamide syringe filter into 1.5-mL amber HPLC vials. The compounds were separated on a Thermo Scientific Accucore ODS column (4.6 mm internal diameter $\times 150 \mathrm{~mm}, 2.6 \mu \mathrm{m}$ particle size). Sample trays and a column oven were thermostated at $5{ }^{\circ} \mathrm{C}$ and $30{ }^{\circ} \mathrm{C}$, respectively. Water (A) and methanol (B), both containing $0.1 \%$ of formic acid $(v / v)$, were used as the mobile phase. A gradient from $5 \%$ to $95 \%$ of solvent B in $20 \mathrm{~min}$ was applied for elution of the targeted molecules. The flow rate of the mobile phase was $1000 \mathrm{~mL} / \mathrm{min}$, and the total time per run was $30.2 \mathrm{~min}$. The wavelength for monitoring the phenolic compounds was set at $280 \mathrm{~nm}$, and UV spectra were recorded from $200 \mathrm{~nm}$ to $400 \mathrm{~nm}$. Peak assignments were achieved by comparing the retention times and UV spectra of the separated compounds to those of analytical standards [21,62]. Quantification of identified compounds was done by comparing peak areas with calibrations made with standards and analyzed under the same conditions. Three chromatograms were recorded for each sample.

The results were expressed as average values of all samples analyzed separately for Scots pine knotwood and black locust heartwood. Results are presented in milligrams of total hydrophilic 
extractives, total phenols, pinosylvin, pinosylvin monomethyl ether robinetin and dihydrorobinetin that were extracted from one gram of dry material $\left(\mathrm{mg} \mathrm{g}^{-1}, \mathrm{dw}\right)$.

Before being tested on the wood-decaying fungi, KWE and HWE were again qualitatively checked for stilbenes and flavonoids by HPLC analysis.

\subsection{Fungal Tests}

\subsubsection{Preparation of Treating Solutions for Antifungal and Decay Testing}

Pure compounds, i.e., pinosylvin (PS), pinosylvin monomethyl ether (PSMME), dihydrorobinetin (DHR) and robinetin (Rob), and hydrophilic extracts of Scots pine knotwood (KWE) and black locust heartwood (HWE) were included in antifungal, decay and antioxidant testing. Pinosylvins were reported to be bioactive compounds [65] and were treated as reference compounds in the present study, in which their properties were compared with robinetins of black locust. The pure compounds (PS, PSMME, DHR and Rob) and the homogenized hydrophilic extracts (KWE and HWE) were freeze-dried in a lyophilizator, as described above. Extractives were then redissolved in dimethyl sulfoxide (DMSO) (for the in vitro antifungal assay) and in water (for the decay assay). KWE and HWE were prepared in two concentrations for the in vitro antifungal assay, as 1\% (KWE1 and HWE1) and 5\% (KWE5 and HWE5) dimethyl sulfoxide solutions ( $w / v)$. Since purified compounds are more difficult to purchase, pinosylvins and robinetins were only prepared as a $1 \%$ solution in DMSO. For the decay test, the aqueous treating solutions containing KWE and HWE were prepared in a concentration of $1 \%(w / v)$. All the prepared mixtures were then homogenized with overnight stirring and with 15-min sonication at room temperature in a Bandelin electronic RK $512 \mathrm{H}$ ultrasonic bath. The treating solutions containing wood extractives were stored in amber glass bottles and placed in a refrigerator.

\subsubsection{Fungal Cultures}

The white-rot fungi Trametes versicolor and Schizophyllum commune (ZIM L039) and brown-rot fungi Gloeophyllum trabeum (ZIM L018) and Fibroporia vaillantii (ZIM L037) were used for the in vitro agar diffusion test. Trametes versicolor and Gloeophyllum trabeum were included in the wood block decay test (decay test). All the fungi used were available in the culture collection of industrial microorganisms of the Biotechnical Faculty, University of Ljubljana [66]. Each fungus was maintained on a previously prepared Petri dish containing potato dextrose agar (PDA, Difco ${ }^{\mathrm{TM}}$ Potato Dextrose Agar, Becton, Dickinson and Company (BD), Sparks, MD, USA). The white- and brown-rot fungi were incubated in a growth chamber at $25^{\circ} \mathrm{C}$ and $85 \%$ relative humidity (RH) for one week [56].

\subsubsection{Antifungal Assay}

The inhibition effect of Scots pine and black locust extractives on the growth of selected white-rot (T. versicolor and S. commune) and brown-rot fungi (G. trabeum and F. vaillantii) was investigated with an in vitro agar well-diffusion method. Briefly, testing solutions of pinosylvin (PS), pinosylvin monomethyl ether (PSMME), dihydrorobinetin (DHR) and robinetin (Rob) and solutions of hydrophilic extracts of Scots pine (KWE1 and KWE5) and black locust (HWE1 and HWE5) were prepared with DMSO. The assay with each of the four fungi was performed on 6 replicates. After autoclaving $\left(p=220 \mathrm{kPa}, T=121^{\circ} \mathrm{C}\right)$, three holes with a diameter of $8 \mathrm{~mm}$ were bored in potato dextrose agar in a Petri dish, and 1 milligram of PS, PSMME, DHR, Rob and hydrophilic KWE and HWE extracts was transferred into the wells. The center of each of the three wells was placed $10 \mathrm{~mm}$ from the edge of the Petri dish. Pure solvent was used in the same volume as for the control. White- and brown-rot fungal inoculums were placed in the center of the Petri dish and stored in a growth chamber, in which incubation followed at $25^{\circ} \mathrm{C}$ and $75 \%$ relative humidity [67]. Growth of the mycelium toward the sites with pinosylvins, robinetins and hydrophilic extracts was measured every 2 to 3 days with a digital Vernier caliper $( \pm 0.01 \mathrm{~mm})$. Fungal growth was determined by measuring the radius of the fungal colony in every direction after subtracting the radius of the inoculum plug. The radial growth of 
the mycelium was measured until the mycelium grew to the edge of the Petri dish in one direction. The results were expressed as the percentage of fungal growth inhibition in a radial direction (FI) and calculated using the following equation:

$$
\mathrm{FI}=\left[\frac{\mathrm{R}_{\mathrm{m}}}{\mathrm{R}_{0}}\right] \cdot 100[\%],
$$

where $R_{m}(\mathrm{~mm})$ distance between the edge of the Petri dish and the mycelia, and $R_{0}(\mathrm{~mm})$ is the distance between the edge of the Petri dish and the edge of the inoculum.

\subsubsection{Impregnation of Wood Blocks for Decay Assay}

A decay test was carried out on sapwood samples of European beech (Fagus sylvatica) and Scots pine (Pinus sylvestris). Beech and Scots pine sapwood blocks were prepared from commercially available sawn timber. Specimen dimensions were $15 \mathrm{~mm}(\mathrm{w}) \times 10 \mathrm{~mm}(\mathrm{~h}) \times 40 \mathrm{~mm}(\mathrm{l})$, and 6 replicates per fungus were used in the decay test. Prior to impregnation, rough edges of the wood blocks were sanded, and samples were then oven-dried at $105^{\circ} \mathrm{C}$ to constant mass. Six wood blocks were placed in a glass beaker in which a plastic mesh was used to prevent direct contact between the wood blocks during the impregnation process. The aqueous solution of Scots pine KWE and black locust HWE were injected into the beakers. Distilled water was used for the impregnation of wood blocks that served as a control. The impregnation of the wood blocks was done in a vacuum-pressure chamber (Kambič Laboratory \& Process Equipment, Semič, Slovenia). The samples were first exposed to a vacuum at $0.9 \mathrm{kPa}$ for $240 \mathrm{~min}$, followed by the main impregnation phase at $900 \mathrm{kPa}$ for $240 \mathrm{~min}$. Impregnated wood blocks were then oven-dried at $105^{\circ} \mathrm{C}$ to constant weight.

\subsubsection{Decay Test}

The decay test was done according to the modified EN 113 standard protocol (CEN, 2006). The mini block test $[68,69]$ was performed for evaluating the decay-retaining properties of Scots pine KWE and black locust HWE on a wood substrate. A Petri dish (dimensions of $\varnothing=85 \mathrm{~mm}, h=21 \mathrm{~mm}$ ) containing 20-mL 3.9\% (aq, w/v) Difco ${ }^{\mathrm{TM}}$ Potato Dextrose Agar (Becton, Dickinson and Company (BD), Sparks, MD, USA) was inoculated with wood-decaying fungi. All the impregnated wood blocks were autoclaved for $20 \mathrm{~min}$ at $220 \mathrm{kPa}$ and $121^{\circ} \mathrm{C}$ before being exposed to the wood-decaying fungi. Wood samples were then carefully placed in a Petri dish containing $0.8 \mathrm{~g}$ of PDA with a thin film of fungus mycelium. A plastic mesh was used to avoid direct contact between the impregnated wood blocks and the growth medium. The assembled test dishes were then incubated at $25{ }^{\circ} \mathrm{C}$ and $80 \%$ relative humidity $(\mathrm{RH})$ for 12 weeks. After incubation, the fungal mycelium was removed from the surface of the wood blocks. Samples were then dried at $105^{\circ} \mathrm{C}$ to constant weight. Mass loss (ML) was determined for control and impregnated wood blocks gravimetrically using the following equation:

$$
\mathrm{ML}=\left[\frac{\left(\mathrm{m}_{\mathrm{dw}, 1}-\mathrm{m}_{\mathrm{dw}, 2}\right)}{\mathrm{m}_{\mathrm{dw}}, 1}\right] \cdot 100[\%],
$$

where $m_{d w, 1}(g)$ is the mass of the wood block before being exposed to wood decaying fungi, and $m_{d w, 2}(g)$ is the mass of the decayed wood block.

\subsection{Assessment of Impregnation Efficiency with Microscopy}

\subsubsection{Sample Preparation}

In order to assess the impregnation efficiency and occurrence of extractives in impregnated wood blocks, additional beech and Scots pine sapwood blocks, measuring $5 \mathrm{~mm} \times 5 \mathrm{~mm} \times 5 \mathrm{~mm}$, were treated with KWE and HWE. Sapwood blocks were impregnated with a water solution of KWE and HWE in a vacuum-pressure chamber. Impregnated sapwood blocks were trimmed with a sliding microtome 
(Leica SM2010R) on the axial and tangential surfaces. Samples were then dried for $72 \mathrm{~h}$ in a vacuum chamber at $10 \mathrm{kPa}$ and room temperature. Untreated/nonimpregnated beech and Scots pine sapwood served as controls. Confocal laser scanning microscope (CLSM) and scanning electron microscopy (SEM) were used for observation.

\subsubsection{Confocal Laser Scanning Microscope (CLSM)}

Dried samples were observed under a CLSM (LEXT OLS5000 3D, Olympus Corporation, Tokyo, 163-0914, Japan) with the following objectives: MPLFLN5x (numerical aperture 0.15, working distance 20), MPLFLN10xLEXT (numerical aperture 0.3, working distance 10.4), MPLAPON20xLEXT (numerical aperture 0.6, working distance 1) and MPLAPON50xLEXT (numerical aperture 0.95, working distance 0.35 ). Color digital images were acquired using wood autofluorescence and using polarized light. CLSM enabled color images to be obtained to observe the different appearance of wood with and without extracts.

\subsubsection{Scanning Electron Microscopy (SEM)}

Dried samples were mounted on stubs with a conductive carbon adhesive, Table 1. Samples were then coated with Au/Pd sputter-coater (Q150R ES Coating System; Quorum Technologies, Laughton, UK) for $30 \mathrm{~s}$ with 20-mA intensity, after which, SEM micrographs were taken at 5-kV voltage under both high and low vacuum conditions with an Everhart-Thornley (ETD) detector in a FEI Quanta 250 SEM microscope (FEI Company, Hillsboro, OR, USA) at a working distance between 9 and $11 \mathrm{~mm}$.

Table 1. Average amounts of extractives gained from individual knotwood samples of Scots pine (Pinus sylvestris) and heartwood samples of black locust (Robinia pseudoacacia). Results are expressed in milligrams of extracted compounds per gram of dried wood $\left(\mathrm{mg} \mathrm{g}^{-1}, \mathrm{dw}\right)$.

\begin{tabular}{ccc}
\hline & Mean & $\mathbf{S D}$ \\
\cline { 2 - 3 } & $\left.\mathbf{( m g ~ g}^{-\mathbf{1}} \mathbf{~ d w}\right)$ & $\left.\mathbf{( m g ~ g ~}^{-\mathbf{1}} \mathbf{~ d w}\right)$ \\
\hline Knotwood Samples of Scots Pine & & \\
Total hydrophilic extractives & 72.8 & 31.56 \\
Total phenols & $33.3^{*}$ & 5.71 \\
Pinosylvin & 10.6 & 4.02 \\
Pinosylvin monomethyl ether & 17.7 & 3.82 \\
\hline Heartwood Samples of Black Locust & & \\
Total hydrophilic extractives & 61.8 & 21.60 \\
Total phenols & 24.8 & 12.58 \\
Robinetin & 4.5 & 2.38 \\
Dihydrorobinetin & 17.8 & 7.51 \\
\hline
\end{tabular}

Results are expressed as the mean value of measurements (mean) with standard deviations (SD). ${ }^{*}$ An asterisk indicates a statistically significant difference in the content of total phenols between knotwood samples of Scots pine and heartwood samples of black locust at a 95.0\% confidence level (Fisher's least significant difference procedure).

\subsection{Assessment of Impregnation Efficiency with Gravimetry}

In the context of the above-described impregnation of beechwood and pinewood blocks for the decay test, the retention of the extracts in the wood blocks was also measured by gravimetric analysis. Wood blocks were oven-dried at $105^{\circ} \mathrm{C}$ to constant weight before and after impregnation. The amount of retained extract in the wood was expressed by the percentage of gained weight (\%), as presented by the equation below [69].

$$
\mathrm{GW}=\left[\frac{\left(\mathrm{m}_{\mathrm{dw}, \mathrm{imp}}-\mathrm{m}_{\mathrm{dw}}\right)}{\mathrm{m}_{\mathrm{dw}}}\right] \cdot 100[\%],
$$

where $m_{d w}(g)$ is the mass of the dried wood block $(g)$, and $m_{d w, i m p}(g)$ is the mass of the impregnated and dried wood block $(\mathrm{g})$. 


\subsection{Antioxidant Assay (a DPPH Radical Scavenging Activity)}

The 2,2-diphenyl-1-picrylhydrazyl (DPPH) radical scavenging activity of Scots pine KWE and black locust HWE were measured according to the modified method as described [50,70-72]. KWE and HWE were redissolved in water. Aqueous solutions of gallic acid (GA), ascorbic acid (AA) and butylhydroxyanisole (BHA) were used as reference. The solutions of KWE and HWE and reference antioxidants were tested for antioxidant activity in five testing concentrations, i.e., $1000 \mathrm{mg} \mathrm{L}^{-1}$, $500 \mathrm{mg} \mathrm{L}^{-1}, 250 \mathrm{mg} \mathrm{L}^{-1}, 100 \mathrm{mg} \mathrm{L}^{-1}$ and $50 \mathrm{mg} \mathrm{L}^{-1}$. Water alone was used as a control. A $2.25 \mathrm{~mL}$ of DPPH methanol solution (40 mg L $\left.\mathrm{m}^{-1}, \mathrm{MeOH}\right)$ was mixed with $0.090 \mathrm{~mL}$ of the aqueous solutions of the hydrophilic wood extracts and the reference antioxidants. The reaction was performed in a 4.5-mL disposable macro cell closed with a $10 \times 10-\mathrm{mm}$ polyethylene lid. The reaction mixtures were then incubated in the dark at room temperature for $30 \mathrm{~min}$. The macro cell was directly placed in a UV-Vis spectrophotometer Lambda (Perkin Elmer, Waltham, MA, USA) after incubation, and the reduction of DPPH radical was measured by taking absorbance at $517 \mathrm{~nm}$. The measurements were taken in triplicate. The DPPH radical scavenging activity (RSA) was measured on the basis of the color change of the DPPH solution. Results were calculated using the equation:

$$
\mathrm{RSA}=\left[\frac{\left(\mathrm{A}_{517 \mathrm{~nm}, \mathrm{DPPH}}-\mathrm{A}_{517 \mathrm{~nm}, \mathrm{~s}}\right)}{\mathrm{A}_{517 \mathrm{~nm}, \mathrm{DPPH}}}\right] \cdot 100[\%],
$$

where $A_{517} \mathrm{~nm}, \mathrm{DPPH}$ is the absorbance at $517 \mathrm{~nm}$ of the control DPPH solution, and $\mathrm{A}_{517 \mathrm{~nm}, \mathrm{~S}}$ is the absorbance at $517 \mathrm{~nm}$ of the wood extract and/or reference antioxidant.

\subsection{Statistics}

The results of the present investigation were analyzed for statistical significance by Statgraphics software. The data were first checked for normal distribution. ANOVA was used to test differences between the means of measurements, and Fisher's least significant difference (LSD) procedure was performed to indicate which means were significantly different from others at a $95.0 \%$ confidence level.

\section{Results and Discussion}

\subsection{Extraction Yields and Chemical Composition of Extracts}

The quantities of compounds extracted from knotwood samples of Scots pine and heartwood samples of black locust are presented in Table 1. One gram of the wood material gave comparable amounts of total hydrophilic extractives (THE), i.e., $72.78 \mathrm{mg}$ THE for Scots pine knotwood and $61.83 \mathrm{mg}$ THE for black locust heartwood (ANOVA, $p>0.050$ ). In comparison to the black locust samples, extraction of Scots pine knotwood yielded significantly larger amounts of total phenols (Table 1) (ANOVA, $p<0.050$ ). The characteristic and most abundant compound of knotwood hydrophilic extracts of Scots pine was pinosylvin monomethyl ether (PSMME) (Figures 1 and 2). DHR was the characteristic compound of the acetone extracts of black locust heartwood (Figures 1 and 3). 


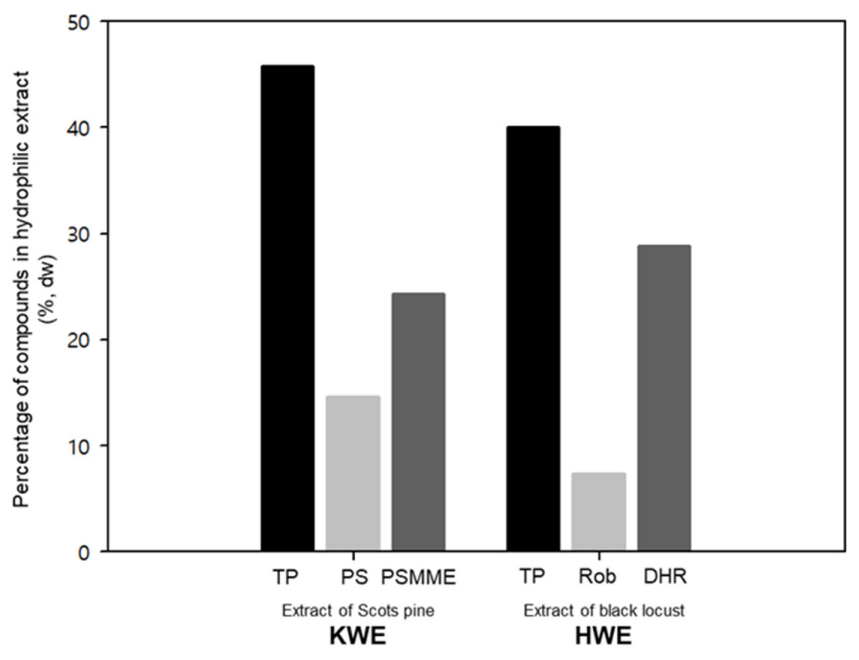

Figure 1. Chemical composition of homogenized extract of Scots pine knotwood (KWE) and homogenized extract of black locust heartwood (HWE). Shares of total phenols (TP), pinosylvin (PS), pinosylvin monomethyl ether (PSMME), robinetin (Rob) and dihydrorobinetin (DHR) in the dried hydrophilic extracts.
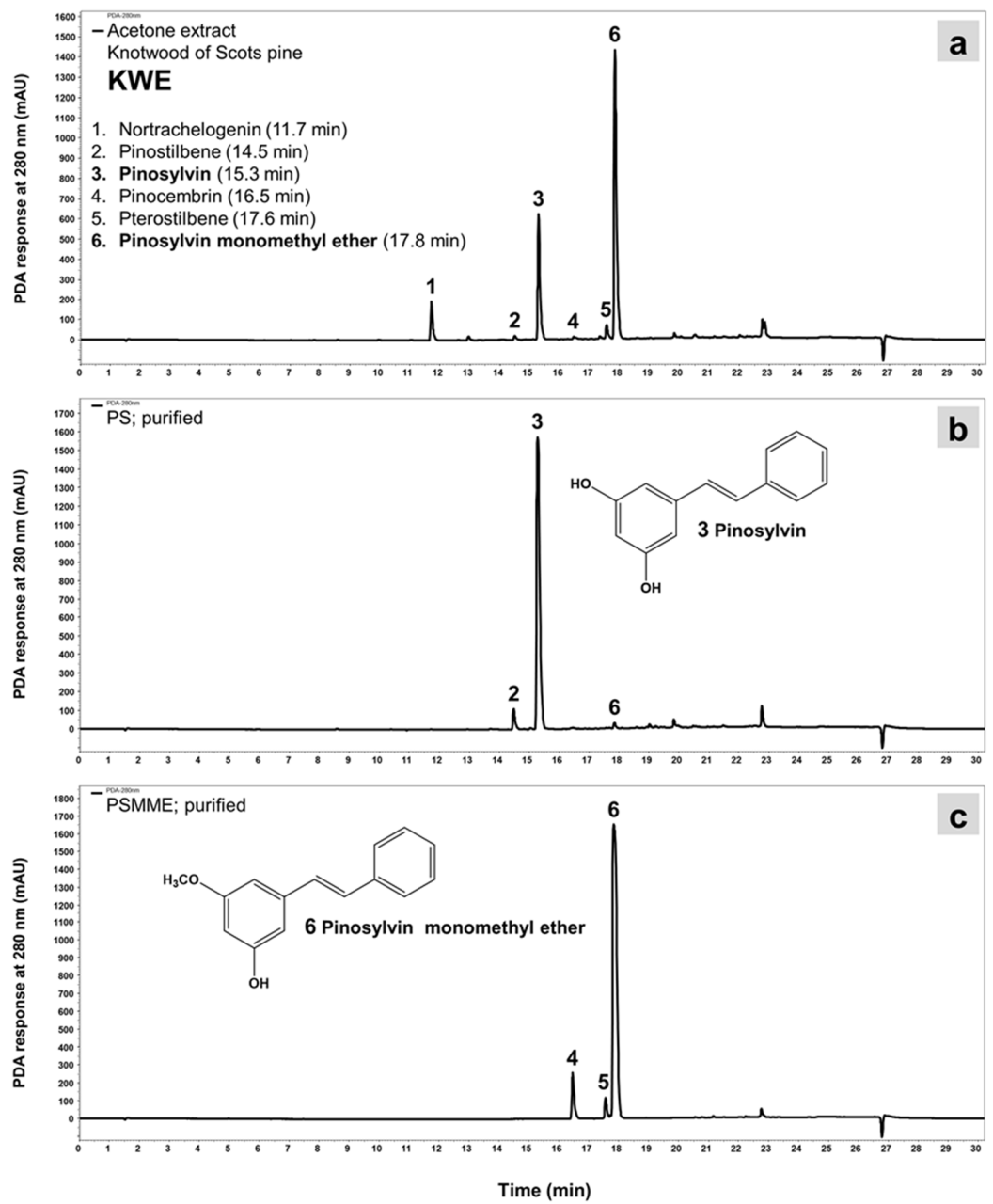

Figure 2. High-performance liquid chromatography-potato dextrose agar (HPLC-PDA) chromatograms of Scots pine (Pinus sylvestris). (a) Homogenized acetone extract of knotwood (KWE), (b) pure pinosylvin used for the antifungal assay and (c) pure pinosylvin monomethyl ether used for the antifungal assay. 

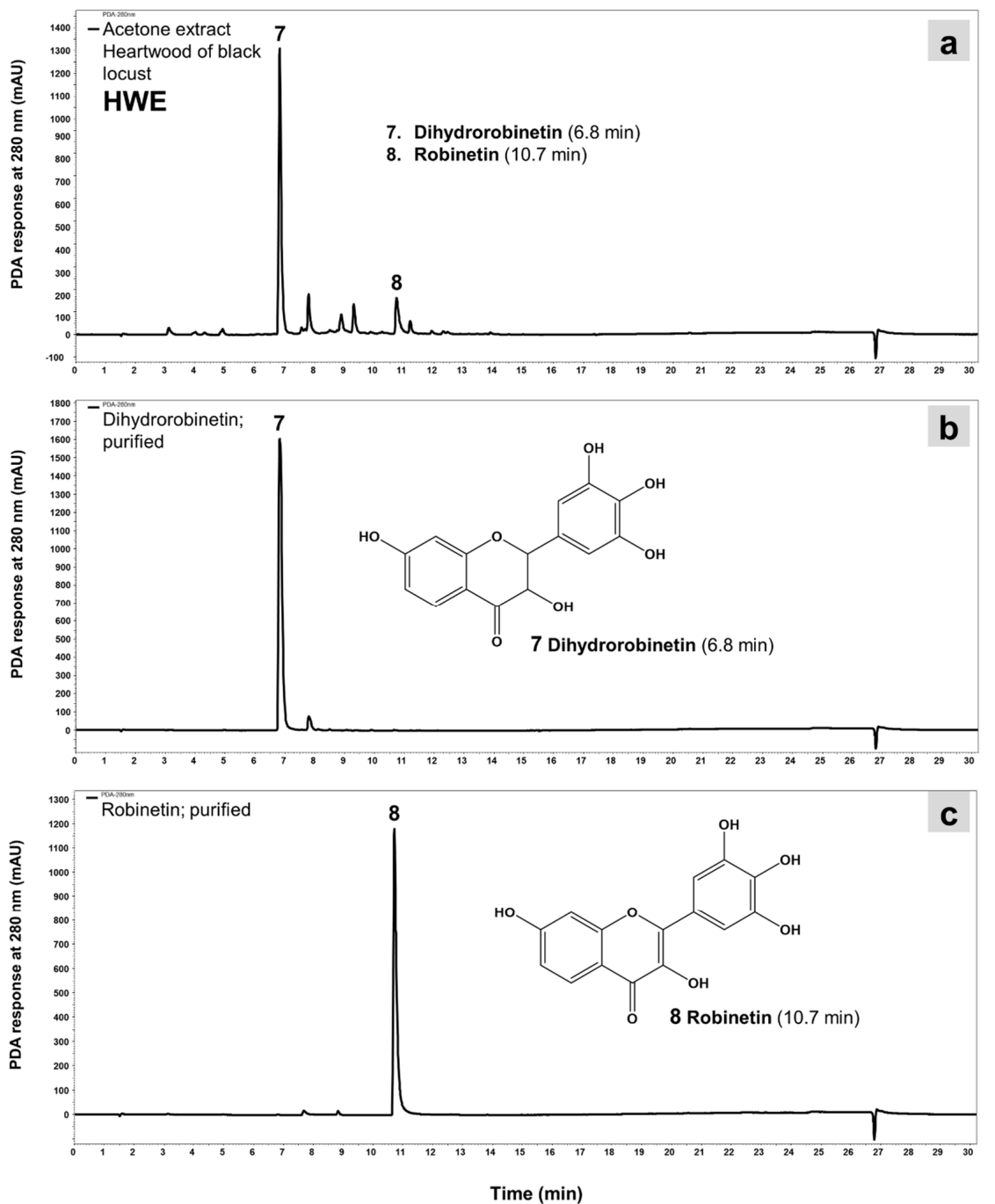

Figure 3. HPLC-PDA chromatograms of black locust (Robinia pseudoacacia). (a) Homogenized acetone extract of heartwood (HWE), (b) pure dihydrorobinetin (DHR) used for the antifungal assay and (c) pure robinetin (Rob) used for the antifungal assay.

For fungal, antioxidant and decay testing, $13.09 \mathrm{~g}$ of KWE and $14.84 \mathrm{~g}$ of dried HWE were prepared. The chemical composition of the two homogenized extracts are presented in Figure 1. The homogenized hydrophilic extract of Scots pine knotwood (KWE) contained larger amounts of total phenols (46\%) than the homogenized hydrophilic extract of black locust heartwood (HWE) (40\% of HWE). KWE consisted of 15\% PS and 24\% PSMME, while HWE was characterized by $7 \%$ Rob and $29 \%$ DHR (Figure 1). Further investigation revealed that almost $72 \%$ of the total phenols (TP) in HWE are described by DHR. In terms of KWE of Scots pine, the share of PSMME in the TP of Scots pine KWE was $53 \%$, and the proportion of PS was $32 \%$ in the TP.

In addition to PS and PSMME, nortrachelogenin, pinostilbene, pinocembrin and pterostilbene were identified in KWE by HPLC analysis (Figure 2). HPLC peaks that were assigned to these compounds were characterized by a weak detector response (Figure 2). A HPLC trace of HWE showed three unidentified compounds eluted between DHR and Rob, i.e., between $t r=7.5 \mathrm{~min}$ and $t r=10 \mathrm{~min}$ (Figure 3). 


\subsection{Occurrence of Extractives and Gained Weight after Impregnation of Wood Blocks}

CLSM and SEM demonstrated that KWE and HWE were introduced and retained in the sapwood of beech and Scots pine (Figures 4-7). CLSM microscopy revealed HWE as yellowish deposits on the surface of the longitudinal sections of both beech (Figure 4) and Scots pine sapwood (Figure 5). The wood surface treated with KWE was slightly darker (Figures $4 \mathrm{~d}$ and $5 \mathrm{~d}$ ) in comparison to the untreated wood (Figures $4 \mathrm{c}$ and $5 \mathrm{c}$ ).

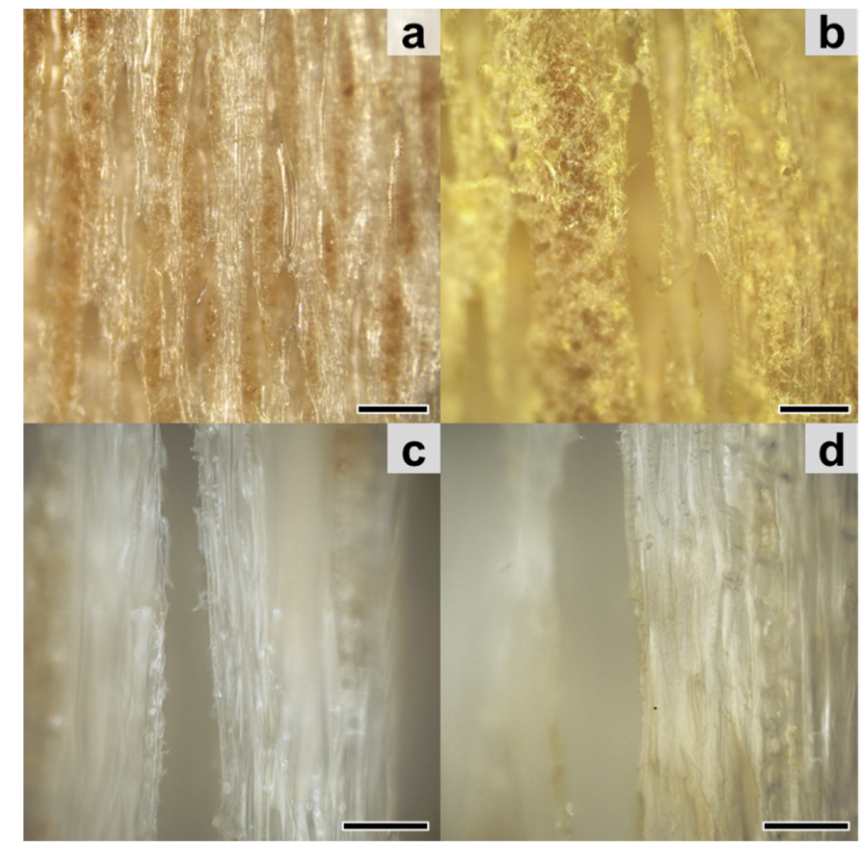

Figure 4. Confocal laser scanning microscope (CLSM) micrographs of untreated (a,c), HWE-treated (b) and KWE-treated (d) tangential sections of beech sapwood (Fagus sylvatica). Magnifications of 10×, 20× and $50 \times$.

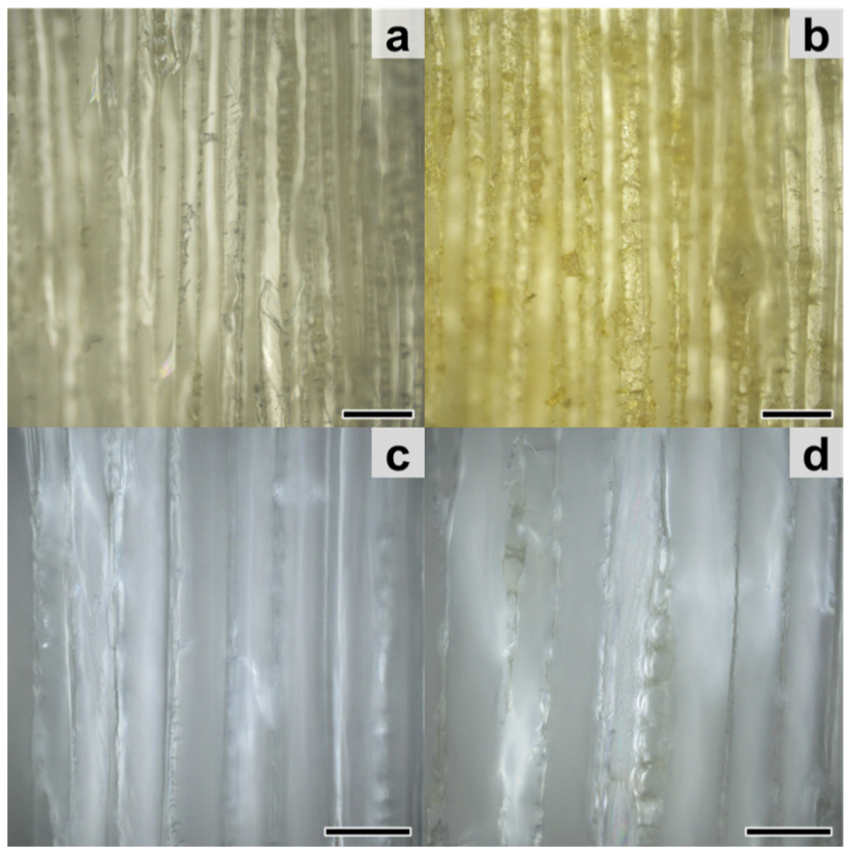

Figure 5. CLSM micrographs of untreated (a,c), HWE-treated (b) and KWE-treated (d) tangential sections of Scots pine sapwood (Pinus sylvestris). Magnifications of $10 \times, 20 \times$ and $50 \times$. 


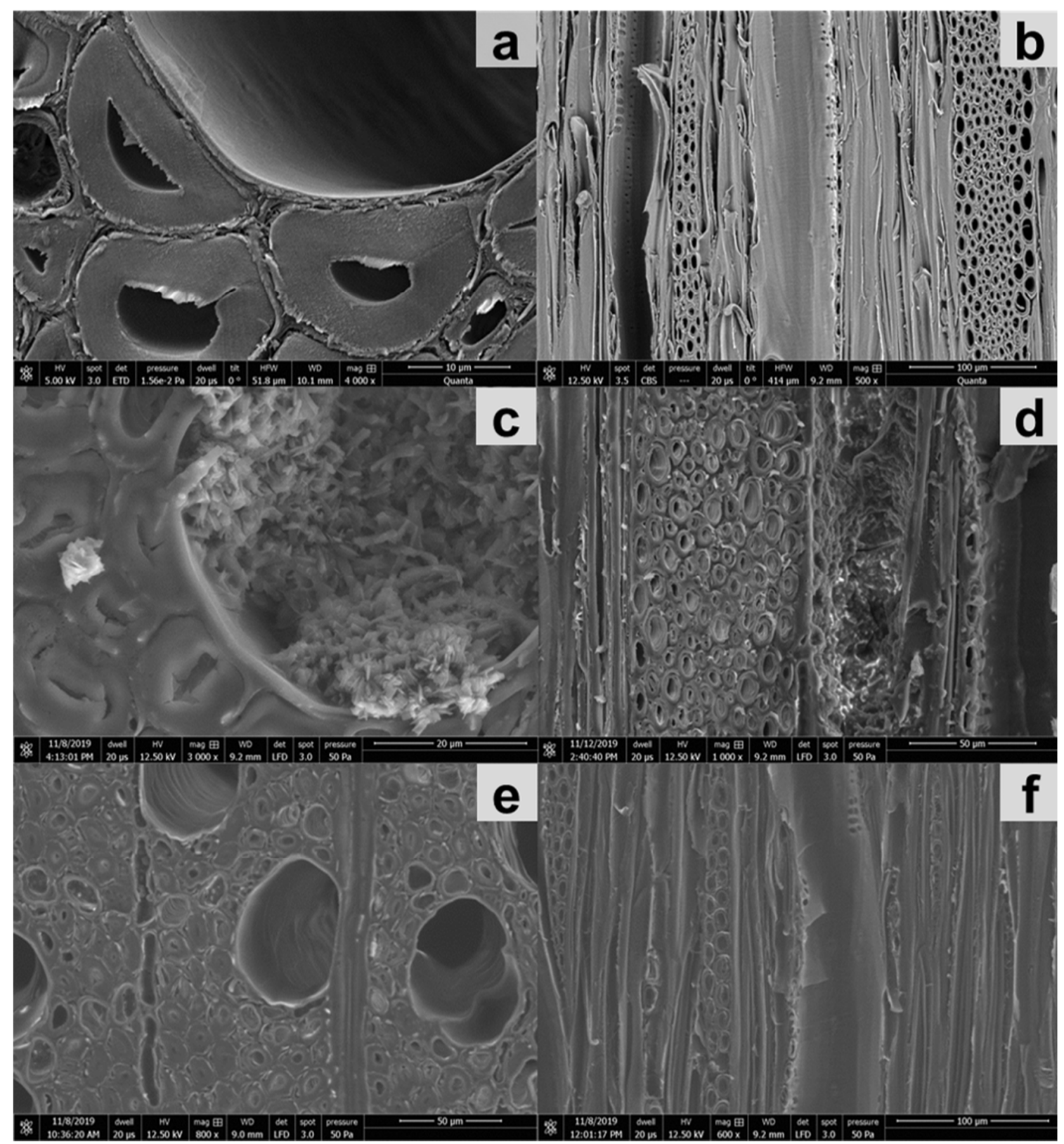

Figure 6. SEM micrographs of beech sapwood (Fagus sylvatica) treated with extractives. (a,b) Untreated wood block. (c,d) Beech wood treated with the heartwood extract of black locust (HWE). (e,f) Beech wood treated with knotwood extract of Scots pine (KWE). (a,c,e) Transverse sections. (b,d,f) Longitudinal sections. The images were obtained at magnifications of 500×, 1000×, 2500×, 4000× and 5000×. 


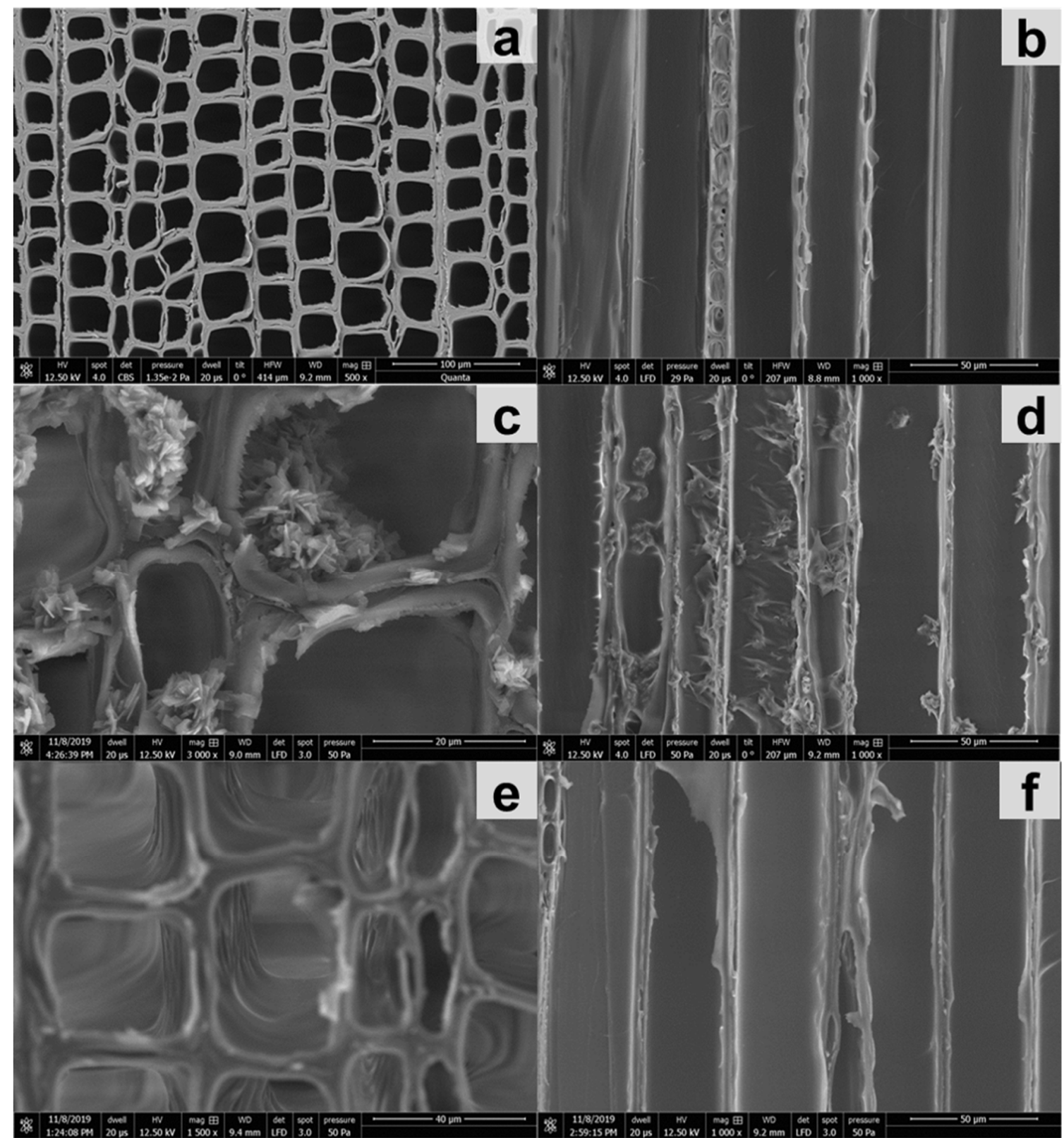

Figure 7. SEM micrographs of Scots pine sapwood (Pinus sylvestris) treated with extractives. $(\mathbf{a}, \mathbf{b})$ Untreated Scots pine sapwood. (c,d) Scots pine sapwood block treated with the heartwood extract of black locust (HWE). (e,f) Scots pine sapwood block treated with knotwood extract of Scots pine (KWE). (a,c,e) Transverse sections. (b,d,f) Longitudinal sections. The images were obtained at magnifications of $1000 \times, 1300 \times, 2500 \times$ and $8000 \times$.

More detailed information on the impregnation efficiency of pinewood and beechwood with the two extracts was obtained by SEM analysis. In wood blocks treated with HWE, crystal-like structures were observed in the lumina of cells (Figure 8). Due to albescence of these structures in the wood of the control samples, we assume that they represent dry HWE. Drying was a necessary step in the preparation of samples for SEM. HWE was deposited in the form of crystal-like structures in the lumina of vessels, fiber tracheids (Figures $6 \mathrm{c}$ and $8 \mathrm{a}$ ) and ray parenchyma cells (Figure 6d), as well as on the surface of the transversely cut cell walls in beech (Figure 6c,d and Figure 8a). In Scots pine sapwood, HWE occurred in the lumina of earlywood tracheids and in the lumina of ray parenchyma (Figure $7 \mathrm{c}, \mathrm{d}$ and Figure $8 c, d$ ). 


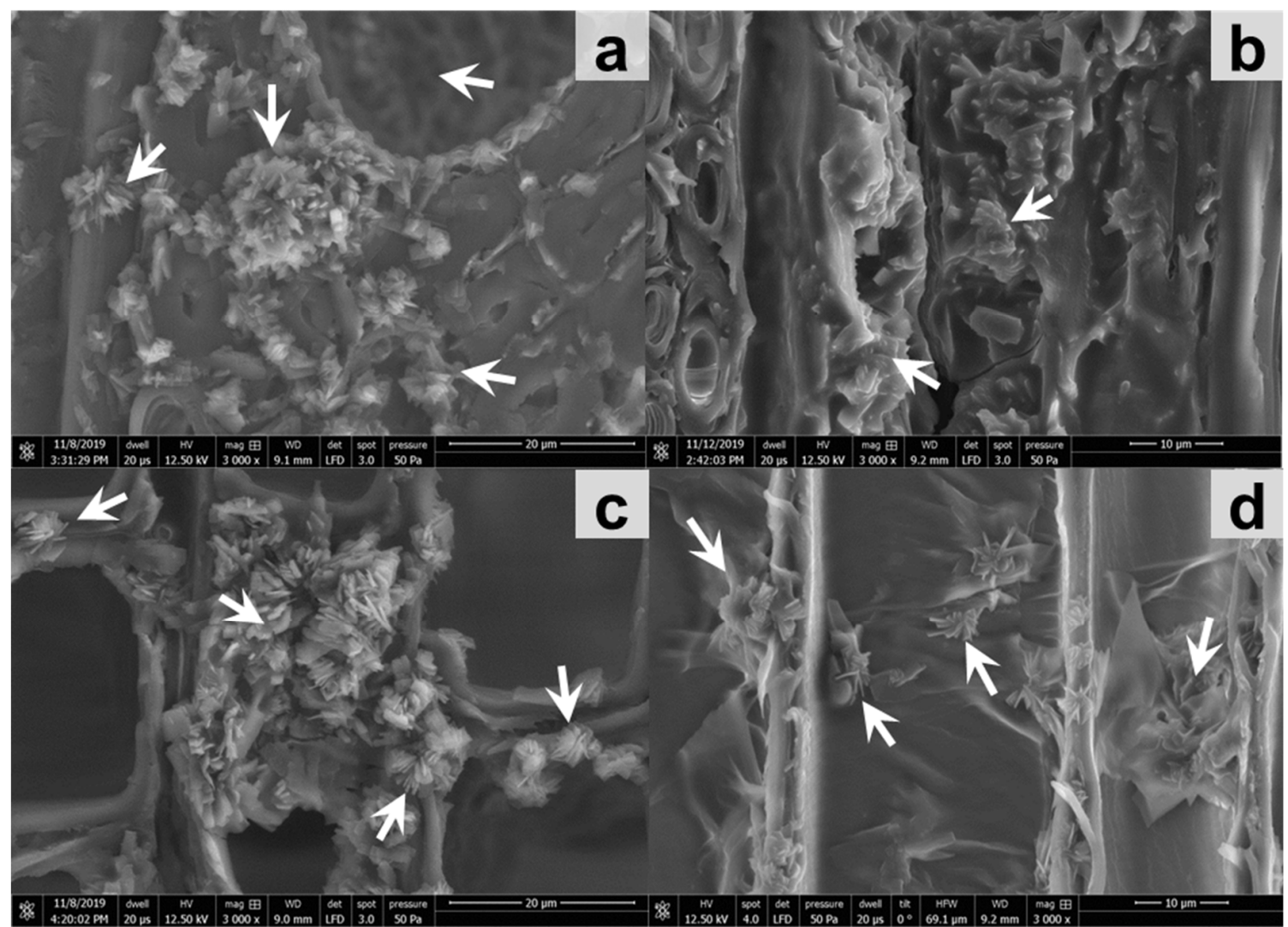

Figure 8. SEM micrographs of crystal-like structures in the lumina of cells in wood impregnated with the heartwood extract of black locust (HWE). (a,b) Beech sapwood (Fagus sylvatica) treated with the HWE. (c,d) Scots pine sapwood (Pinus sylvestris) treated with the HWE. (a,c) Transverse sections. $(\mathbf{b}, \mathbf{d})$ Longitudinal sections. The images were obtained at a magnification of $3000 \times$.

In wood blocks treated with KWE, an opaque layer was observed, covering the cell walls of the vessels, fiber tracheids and parenchyma in beech (Figure 6e,f), as well as the walls of tracheids and parenchyma in Scots pine (Figure 7e,f). This layer was absent from the control wood samples (Figure 6a,b and Figure 7a,b).

Data for the GW (Table 2) show that the uptakes of the two treating solutions were significantly different in beechwood and pinewood (ANOVA, $p<0.050$ ). Uptakes of KWE and HWE in Scots pine sapwood were higher than those for beechwood (LSD test) (Table 2) under the same impregnation conditions. These results could be ascribed to the higher porosity and longitudinal permeability of pine wood [73]. The highest GW of the wood samples was achieved by impregnation with HWE (LSD test) (Table 2). We assume that this is explained by the higher polarity of HWE extractives (chemical structures of DHR and Rob on Figure 3) and, consequently, by the higher solubility and retention of DHR and Rob flavonoids on the hydrophilic cell wall substrate. The presence of partially nonpolar compounds (e.g., PSMME) in the Scots pine hydrophilic extracts can be explained by a lower uptake of the KWE-treating solution (Table 2) [74-76].

Table 2. Gained weight (GW, \%) for impregnated beech and Scots pine sapwood.

\begin{tabular}{ccc}
\hline Sapwood Blocks & GW (\%) KWE & GW (\%) HWE \\
\hline Fagus sylvatica & $0.52 \pm 0.07^{\mathrm{a}}$ & $0.84 \pm 0.09^{\mathrm{b}}$ \\
Pinus sylvestris $^{\mathrm{a}}$ & $0.61 \pm 0.14^{\mathrm{a}}$ & $1.06 \pm 0.14^{\mathrm{c}}$ \\
\hline
\end{tabular}

Results are expressed as the mean value of the measurements with standard deviations. $\left({ }^{a-c}\right)$ Different letters indicate statistically significant differences at a 95.0\% confidence level (Fisher's least significant difference procedure). GW $(\%, w / w)$, gained weight representing the amount of retained extract in the wood blocks. 


\subsection{Fungal Growth Inhibition of Scots Pine and Black Locust Extractives}

The antifungal in vitro assay showed significant differences in fungal growth inhibition (FI) among the tested compounds and KWE and HWE (ANOVA, $p<0.001$ ). The largest FI was shown by PS and PSMME (LSD test). The inhibition was especially conspicuous against the growth of G. trabeum (Table 3). The FI of PS was weaker than that shown by PSMME (Table 3).

Table 3. Fungal growth inhibition (FI, \%) of white-rot and brown-rot-producing fungi by pure compounds (PS, PSMME, DHR and Rob) and HWE and KWE.

\begin{tabular}{ccccc}
\hline & $\begin{array}{c}\text { Trametes } \\
\text { Versicolor (\%) }\end{array}$ & $\begin{array}{c}\text { Schizophyllum } \\
\text { Commune (\%) }\end{array}$ & $\begin{array}{c}\text { Gloeophyllum } \\
\text { Trabeum (\%) }\end{array}$ & $\begin{array}{c}\text { Fibroporia } \\
\text { Vaillantii (\%) }\end{array}$ \\
\hline Control (DMSO) & $0.00 \pm 0.00^{\mathrm{a}}$ & $0.00 \pm 0.00^{\mathrm{a}}$ & $0.00 \pm 0.00^{\mathrm{a}}$ & $0.00 \pm 0.00^{\mathrm{a}}$ \\
\hline $\begin{array}{c}\text { Extractives of Scots Pine } \\
\text { PS (Ref 1) }\end{array}$ & $14.05 \pm 1.02^{\mathrm{c}}$ & $42.38 \pm 5.80^{\mathrm{c}}$ & $42.06 \pm 0.71^{\mathrm{b}}$ & $36.91 \pm 11.34^{\mathrm{b}, \mathrm{c}}$ \\
PSMME (Ref 2) & $25.76 \pm 1.77^{\mathrm{d}}$ & $57.67 \pm 5.20^{\mathrm{d}}$ & $67.62 \pm 2.85^{\mathrm{d}}$ & $48.95 \pm 20.15^{\mathrm{c}}$ \\
KWE1 & $10.85 \pm 2.83^{\mathrm{b}}$ & $37.03 \pm 5.26^{\mathrm{b}}$ & $42.40 \pm 1.43^{\mathrm{b}}$ & $21.97 \pm 18.47^{\mathrm{b}}$ \\
KWE5 & $12.79 \pm 4.22^{\mathrm{b}, \mathrm{c}}$ & $41.18 \pm 5.19^{\mathrm{c}}$ & $50.64 \pm 3.86^{\mathrm{c}}$ & $24.43 \pm 18.02^{\mathrm{b}}$ \\
\hline & & & & \\
Extractives of Black & & & & \\
Locust & & & & \\
DHR & $0.00 \pm 0.00^{\mathrm{a}}$ & $0.00 \pm 0.00^{\mathrm{a}}$ & $0.00 \pm 0.00^{\mathrm{a}}$ & $3.12 \pm 3.63^{\mathrm{a}}$ \\
Rob & $0.00 \pm 0.00^{\mathrm{a}}$ & $0.00 \pm 0.00^{\mathrm{a}}$ & $0.00 \pm 0.00^{\mathrm{a}}$ & $6.20 \pm 2.46^{\mathrm{a}}$ \\
HWE1 & $0.00 \pm 0.00^{\mathrm{a}}$ & $0.00 \pm 0.00^{\mathrm{a}}$ & $0.00 \pm 0.00^{\mathrm{a}}$ & $3.52 \pm 4.37^{\mathrm{a}}$ \\
HWE5 & $0.00 \pm 0.00^{\mathrm{a}}$ & $0.00 \pm 0.00^{\mathrm{a}}$ & $0.00 \pm 0.00^{\mathrm{a}}$ & $5.10 \pm 6.94^{\mathrm{a}}$ \\
\hline
\end{tabular}

Results are expressed as the mean value of measurements with standard deviations. ${ }^{\mathrm{a}-\mathrm{d}}$ ) Different letters within the same column indicate statistically significant differences at a 95.0\% confidence level (Fisher's least significant difference procedure). C, control; PS, pinosylvin; PSMME, pinosylvin monomethyl ether; DHR, dihydrorobinetin; Rob, robinetin; KWE1 and KWE5, hydrophilic extracts of Scots pine knotwood (1\% and 5\%, w/v) and HWE1 and HWE5, hydrophilic extracts of black locust heartwood $(1 \%$ and $5 \%, w / v)$.

A 5\% water solution of Scots pine knotwood extract (KWE5) had better FI than KWE1. The higher concentration of KWE used in plate tests played a significant role in the FI of S. commune and G. trabeum. The amount of KWE did not have a significant influence on the growth of T. versicolor and F. vaillantii. KWE5 had weaker FI than PSMME and comparable antifungal properties to pure PS (LSD test). KWE5 showed greater FI towards the G. trabeum than pure PS (LSD test). The growth of brown-rot fungi G. trabeum and F. vaillantii was affected to the same extent using either pure PS or KWE1 (LSD test). The results of the test on plates did not show any fungicidal properties of DHR, Rob and hydrophilic extracts of black locust heartwood (HWE1 and HWE5) (Table 3). The black locust extractives did inhibit the growth of F. vaillantii; however, their FI were found to be irrelevant when compared with the knotwood extractives of Scots pine (Table 3).

\subsection{Decay Resistance of Wood Impregnated with Scots Pine and Black Locust Extractives}

The decay assay with the mini block test showed a significant influence of KWE and HWE on the mass loss (ML) of beech and pine sapwood exposed to the wood-decaying fungi (Table 4). The ML of the impregnated beech and pine sapwood exposed to Trametes versicolor was not significantly different from that of the control samples (Table 4). T. versicolor is considered to be a nonselective type of fungus, which is capable of degrading all the structural components of a woody cell wall, viz., lignin and hemicelluloses, as well as cellulose [77]. On the other hand, T. versicolor is also known to be a better degrader of hardwoods and to have a limited effect on softwoods. This is in accordance with our results, in which the ML of nontreated beechwood blocks exposed to T. versicolor was significantly larger than the ML of pinewood control blocks (Table 4). The exact opposite was found for the impregnated wood blocks exposed to Gloeophyllum trabeum. Here, a significantly smaller ML was found for KWE and HWE-impregnated beech and Scots pine wood than for the corresponding control samples (Table 4) (LSD test). The decay assay showed a small ML, especially in the case of Scots pine 
sapwood impregnated with HWE (Table 4). The ML for KWE and HWE-impregnated Scots pine and beech sapwood samples exposed to G. trabeum were comparable.

Table 4. Mass loss (ML, \%) of KWE and HWE-impregnated beech and Scots pine sapwood exposed to white-rot (Trametes versicolor) and brown-rot fungi (Gloeophyllum trabeum) for 12 weeks.

\begin{tabular}{ccccc}
\hline Sapwood Blocks of & Fungal Culture & ML (\%) C & ML (\%) KWE & ML (\%) HWE \\
\hline Fagus sylvatica & Trametes versicolor & $9.17 \pm 1.72^{\mathrm{c}, \mathrm{d}}$ & $7.75 \pm 1.48^{\mathrm{b}, \mathrm{c}, \mathrm{d}}$ & $7.04 \pm 1.04^{\mathrm{b}, \mathrm{c}}$ \\
& Gloeophyllum trabeum & $10.18 \pm 2.23^{\mathrm{d}}$ & $3.09 \pm 1.61^{\mathrm{a}}$ & $5.23 \pm 2.03^{\mathrm{a}, \mathrm{b}}$ \\
\hline Pinus sylvestris & & & \\
& Trametes versicolor & $7.30 \pm 0.84^{\mathrm{b}}$ & $5.42 \pm 0.87^{\mathrm{a}, \mathrm{b}}$ & $4.89 \pm 1.16^{\mathrm{a}, \mathrm{b}}$ \\
& Gloeophyllum trabeum & $22.46 \pm 3.87^{\mathrm{c}}$ & $3.36 \pm 3.84^{\mathrm{a}}$ & $2.17 \pm 2.58^{\mathrm{a}}$ \\
\hline
\end{tabular}

Results are expressed as the mean value of measurements with standard deviations. ${ }^{\left({ }^{a-d}\right)}$ Different letters indicate statistically significant differences at a 95.0\% confidence level (Fisher's least significant difference procedure). ML $(\%, w / w)$, mass loss of beech and Scots pine wood block after exposure to the wood-decaying fungi. C, control (distilled $\mathrm{H}_{2} \mathrm{O}$ ).

\subsection{Radical Scavenging Activity of Wood Extracts}

HWE showed higher DPPH free radical scavenging activity (RSA) than KWE in the whole concentration range tested (Figure 9). HWE exhibited higher RSA than ascorbic acid and comparable to butylhydroxyanisole even at lower concentrations, i.e., at $50 \mathrm{mg} \mathrm{L}^{-1}$ and $100 \mathrm{mg} \mathrm{L}^{-1}$ (Figure 9) (LSD test). The RSA of HWE was comparable to the RSA of gallic acid and ascorbic acid at concentrations of $250 \mathrm{mg} \mathrm{L}^{-1}, 500 \mathrm{mg} \mathrm{L}^{-1}$ and $1000 \mathrm{mg} \mathrm{L}^{-1}$. Butylhydroxyanisole possessed comparable RSA only at $500 \mathrm{mg} \mathrm{L}^{-1}$ and at $1000 \mathrm{mg} \mathrm{L}^{-1}$. The best RSA was shown by gallic acid (GA) (LSD test). KWE exhibited the lowest RSA among the tested compounds.

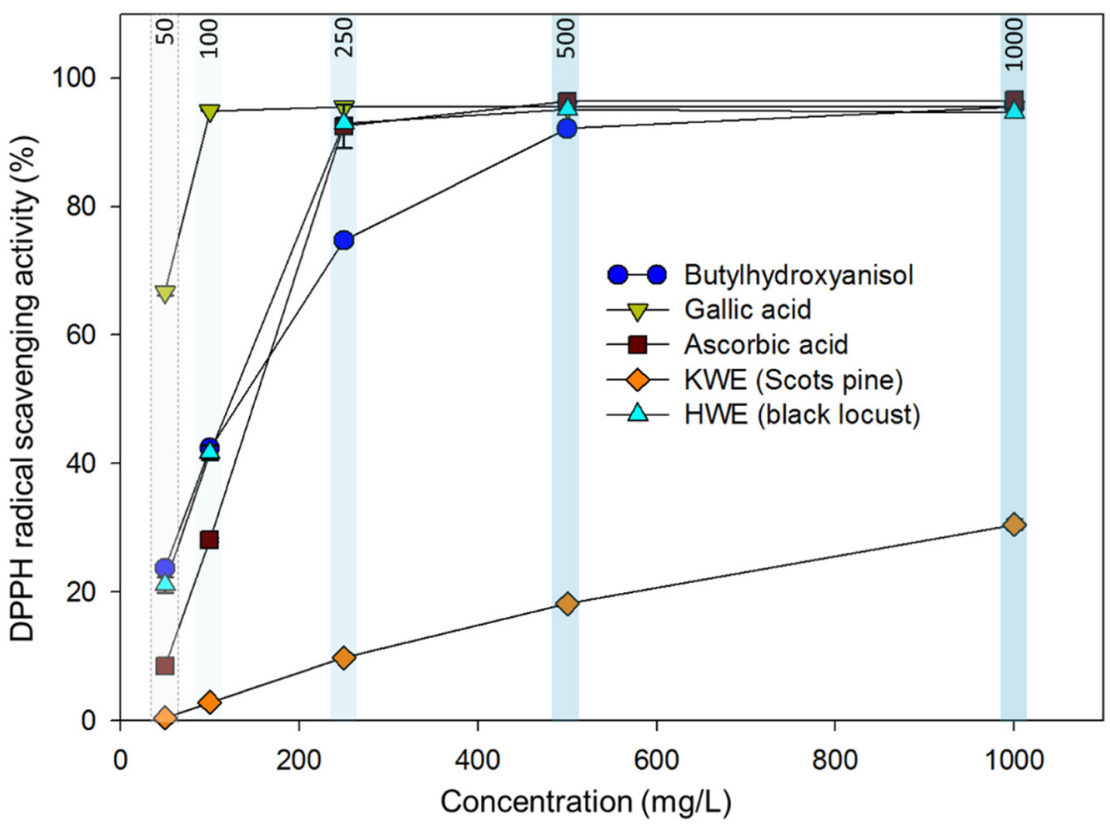

Figure 9. DPPH radical scavenging activity (RSA, \%) for the KWE of P. sylvestris and HWE of $R$. pseudoacacia and references (BHA, GA and AA). BHA, butylhydroxyanisole; GA, gallic acid; AA, ascorbic acid; KWE, treating solution of Scots pine knotwood extract $(1 \%$, w/v) and HWE, treating solution of black locust heartwood extract $(1 \%, w / v)$.

Knotwood hydrophilic extractives of Scots pine (KWE) and pure pinosylvins (PS and PSMME) showed significant fungal inhibitions that were demonstrated by both the test on plates and the 
decay assay (Table 3). On the other hand, they were not good DPPH radical scavengers (Figure 9). The mechanisms by which stilbene-type molecules inhibit the growth of wood-decaying fungi may differ significantly with regard to their chemical structure and polarity. The protection role of phenolic extractives in wood could be explained by both fungicidal and nonbiocidal properties. The latter are radical scavenging (antioxidant) activity and the ability of a compound to form a complex with metals (metal chelators) [78]. A literature review showed that pinosylvins have already been reported to be phytoalexins or bioactive phytochemicals with antioxidant and antifungal properties $[23,26-28,65,79]$. Knotwood extracts of Sots pine have also been reported to have an influence against Fenton-type degradation [23].

In contrast to pure pinosylvins (PS and PSMME) and KWE, the performed antifungal assay showed that black locust extractives did not inhibit the growth of fungi at all (Table 3). Phenolic extractives have been reported to have an important influence on the natural durability of black locust heartwood $[41,42,45]$. On the other hand, the HWE showed quite impressive antioxidant properties, even better than some commercial antioxidants (Figure 9). Not only antioxidant properties but good free radical scavenging has been demonstrated for a fraction isolated from the crude acetone extract of black locust heartwood containing alkanes, simple phenols, phthalates and fatty acids [47]. In addition to the described antifungal mechanisms, the ability of a molecule for radical scavenging has already been reported to be an important factor that restricts fungal decay [23,50]. Radical scavenging activity has been reported to be an important defense mechanism against both white- and brown-rot fungi. It has been suggested that wood-decaying fungi use nonenzymatic agents for the degradation of the wood cell wall, viz., free radicals produced by the Fenton reaction $[23,26,80]$. Particularly brown-rot decaying fungi are known to use free radicals in order initially to disrupt the cell walls to increase the pore size so that the relatively large extracellular fungal enzymes can penetrate the cell wall $[20,48,54,81,82]$. The results of our investigation suggest that the hydrophilic extractives of black locust heartwood have an important impact on the resistance of wood against wood-decaying fungi, primarily through their antioxidant activity rather than antifungal properties.

Wood degradation by fungi often also involves various metals, either in free form or as key components of enzymes [78]. The radical scavenging activity of pine extractives has been recognized to be more important than their interactions with iron [23]. The importance of the antioxidant activity was also demonstrated by the results of this investigation. In addition to having high antioxidant activity (RSA) potential, the sapwood blocks impregnated with HWE exhibited significantly lower ML than that of the nonimpregnated materials. The antioxidant properties of the extractives could therefore be understood as very important for the development of potential bio-based wood preservatives. Black locust extractives showed a completely opposite effect on the growth of fungi when they were tested on potato dextrose agar in Petri dishes or when they were tested as wood preservatives of sapwood blocks of beech and Scots pine. This could be explained by the fact that nonenzymatic agents that are produced by fungi are not needed for the degradation of the PDA growth media constituents, i.e., potato starch $\left(4 \mathrm{~g} \mathrm{~L}^{-1}\right)$, dextrose $\left(20 \mathrm{~g} \mathrm{~L}^{-1}\right)$ and agar $\left(15 \mathrm{~g} \mathrm{~L}^{-1}\right)$. Fungus hyphae can therefore absorb the substrate as it is, without mobilizing free radicals and extracellular enzymes. Extractives of black locust, with their antioxidant properties, thus had no important antifungal effect in the Petri dish test and were easily overgrown by the fungi. On the other hand, black locust extractives had a major influence on the decay resistance of impregnated sapwood blocks of beech and Scots pine. It can be assumed that heartwood extractives of black locust, with the high radical scavenging activity measured, make the extracellular enzymes of fungi inactive.

\section{Conclusions}

Our study demonstrated that forestry residues and woods of underutilized tree species should be considered to a greater extent as a potential source of natural bioactive compounds with applicable potentials. It can be speculated that wood extractives could also be combined for a synergistic effect, with the goal of developing a benign wood preservative made of "eco-friendly" antioxidants, fungicides 
and water repellents. The potential of combining commercial antioxidants and biocides has already been shown, with interesting results of synergism [14,48,51,52,78]. Phytochemicals from wood are foreseen in the formulations of preservatives as bioactive agents, although they are not at the moment able to compete with synthetic chemicals, characterized by low production costs and long-term efficiency. Some other drawbacks of using natural bioactive compounds for wood preservation are also reflected in the sufficient retention of bioactive compounds in the wood matrix, their susceptibility to degradation and potential cytotoxicological and ecotoxicological threats. The results of the investigation showed the impregnation of less durable sapwood with Scots pine and black locust extracts; these were deposited in the lumina and on the wall surface of cells of the impregnated wood and reduced the fungal decay of the wood. Furthermore, Scots pine extractives were demonstrated as good inhibitors of fungal growth, while black locust extractives were strong free radical scavengers. These findings represent an important step towards the development of bio-based wood preservatives that include extractives from Scots pine and black locust woody biomasses.

Author Contributions: Conceptualization, V.V. and P.O.; methodology, V.V., A.B., M.H. and I.P.; software, V.V. and A.B.; validation, V.V., I.P., A.B. and M.H.; formal analysis, V.V.; investigation, V.V., I.P. and P.O.; resources, V.V. and P.O.; writing —original draft preparation, V.V.; writing—review and editing, V.V., A.B., I.P., M.H. and P.O. and supervision, P.O. and I.P. All authors have read and agreed to the published version of the manuscript.

Funding: This research was funded by the Ministry of Education, Science, and Sport of the Republic of Slovenia grant number 6316-9/2015-142 (postdoc project). Part of the work was performed in the frame of the transnational WoodWisdom ERA-NET project PINOBIO. The authors acknowledge the support of the Slovenian Research Agency within program P4-0015, RDI project Cel.Cycle: "Potential of biomass for development of advanced materials and bio-based products", co-financed by the Republic of Slovenia, Ministry of Education, Science and Sport, and European Union through the European Regional Development Fund, 2016-2020 and the project Applause, UIA02-228 (Urban Innovative Actions).

Acknowledgments: Many thanks to Andreja Žagar, Boštjan Lesar, and Davor Kržišnik for many useful tips and professional technical assistance.

Conflicts of Interest: The authors declare no conflict of interest.

\section{References}

1. Fengel, D.; Wegener, G. Wood: Chemistry, Ultrastructure, Reactions; Walter de Gruyter: Berlin, Germany, $1989 ;$ p. 613.

2. Oleson, K.R.; Schwartz, D.T. Extractives in Douglas-fir forestry residue and considerations for biofuel production. Phytochem. Rev. 2016, 15, 985-1008. [CrossRef]

3. Belgacem, N.; Pizzi, A. Lignocellulosic Fibers and Wood Handbook: Renewable Materials for Today's Environment; Scrivener Publishing: Salem, MA, USA, 2016; p. 669.

4. Chen, H.; Liu, J.; Chang, X.; Chen, D.; Xue, Y.; Liu, P.; Lin, H.; Han, S. A review on the pretreatment of lignocellulose for high-value chemicals. Fuel Process. Technol. 2017, 160, 196-206. [CrossRef]

5. Ragauskas, A.J.; Williams, C.K.; Davison, B.H.; Britovsek, G.; Cairney, J.; Eckert, C.A.; Frederick, W.J.; Hallett, J.P.; Leak, D.J.; Liotta, C.L.; et al. The path forward for biofuels and biomaterials. Science 2006, 311, 484-489. [CrossRef] [PubMed]

6. Humar, M.; Kržišnik, D.; Lesar, B.; Brischke, C. The Performance of Wood Decking after Five Years of Exposure: Verification of the Combined Effect of Wetting Ability and Durability. Forests 2019, 10, 903. [CrossRef]

7. Miebach, F. Design ideas for solid timber bridges. Wood Mater. Sci. Eng. 2018, 13, 184-189. [CrossRef]

8. Hill, C.A.S. Wood modification: An update. BioResources 2011, 6, 918-919.

9. Petrič, M. Surface Modification of Wood. Rev. Adhes. Adhes. 2013, 1, 216-247. [CrossRef]

10. Pitman, A. Deterioration and protection of sustainable biomaterials. Int. Wood Prod. J. 2017, 8, 56. [CrossRef]

11. Humar, M.; Lesar, B.; Thaler, N.; Krzisnik, D.; Kregar, N.; Drnovsek, S. Quality of copper impregnated wood in slovenian hardware stores. Drona Ind. 2018, 69, 121-126. [CrossRef]

12. Karppanen, O.; Venäläinen, M.; Harju, A.M.; Willför, S.; Pietarinen, S.; Laakso, T.; Kainulainen, P. Knotwood as a window to the indirect measurement of the decay resistance of Scots pine heartwood. Holzforschung 2007, 61, 600-604. [CrossRef] 
13. Freeman, M.H.; McIntyre, C.R. A comprehensive review of copper-based wood preservatives. For. Prod. J. 2008, 58, 6-27.

14. Schultz, T.P.; Nicholas, D.D. Efficacy of two organic biocides with co-added antioxidants. Holzforschung 2011, 65, 771. [CrossRef]

15. Ekeberg, D.; Flćte, P.O.; Eikenes, M.; Fongen, M.; Naess-Andresen, C.F. Qualitative and quantitative determination of extractives in heartwood of Scots pine (Pinus sylvestris L.) by gas chromatography. J. Chromatogr. A 2006, 1109, 267-272. [CrossRef] [PubMed]

16. Singh, T.; Singh, A.P. A review on natural products as wood protectant. Wood. Sci. Technol. 2012, 46, 851-870. [CrossRef]

17. Barbero-Lopez, A.; Chibily, S.; Tomppo, L.; Salami, A.; Ancin-Murguzur, F.J.; Venalainen, M.; Lappalainen, R.; Haapala, A. Pyrolysis distillates from tree bark and fibre hemp inhibit the growth of wood-decaying fungi. Ind. Crops. Prod. 2019, 129, 604-610. [CrossRef]

18. Dian-Qing, Y. Potential utilization of plant and fungal extracts for wood protection. For. Prod. J. 2009, 59, 97-103.

19. Kadir, R.; Hale, M. Biocidal potential of the extractives of four Malaysian timbers against subterranean termites and wood decay fungi. Eur. J. Wood Wood Prod. 2019, 77, 147-155. [CrossRef]

20. Valette, N.; Perrot, T.; Sormani, R.; Gelhaye, E.; Morel-Rouhier, M.; Morel-Rouhier, M. Antifungal activities of wood extractives. Fungal Biol. Rev. 2017, 31, 113-123. [CrossRef]

21. Poljanšek, I.; Oven, P.; Vek, V.; Raitanen, J.E.; Hemming, J.; Willför, S. Isolation of pure pinosylvins from industrial knotwood residue with non-chlorinated solvents. Holzforschung 2019, 73, 475-484. [CrossRef]

22. Willför, S.M.; Ahotupa, M.O.; Hemming, J.E.; Reunanen, M.H.T.; Eklund, P.C.; Sjoholm, R.E.; Eckerman, C.S.E.; Pohjamo, S.P.; Holmbom, M.R. Antioxidant activity of knotwood extractives and phenolic compounds of selected tree species. J. Agric. Food Chem. 2003, 51, 7600-7606. [CrossRef]

23. Belt, T.; Hanninen, T.; Rautkari, L. Antioxidant activity of Scots pine heartwood and knot extractives and implications for resistance to brown rot. Holzforschung 2017, 71, 527-534. [CrossRef]

24. Harju, A.M.; Venäläinen, M. Measuring the decay resistance of Scots pine heartwood indirectly by the Folin-Ciocalteu assay. Can. J. For. Res. 2006, 36, 1797-1804. [CrossRef]

25. Lindberg, L.E.; Willför, S.M.; Holmbom, B.R. Antibacterial effects of knotwood extractives on paper mill bacteria. J. Ind. Microbiol. Biotechnol. 2004, 31, 137-147. [CrossRef]

26. Pietarinen, S.; Willför, S.; Ahotupa, M.; Hemming, J.; Holmbom, B. Knotwood and bark extracts: Strong antioxidants from waste materials. J. Wood. Sci. 2006, 52, 436-444. [CrossRef]

27. Välimaa, A.L.; Honkalampi-Hämäläinen, U.; Pietarinen, S.; Willför, S.; Holmbom, B.; von Wright, A. Antimicrobial and cytotoxic knotwood extracts and related pure compounds and their effects on food-associated microorganisms. Int. J. Food Microbiol. 2007, 115, 235-243. [CrossRef]

28. Lu, J.R.; Venalainen, M.; Julkunen-Tiitto, R.; Harju, A.M. Stilbene impregnation retards brown-rot decay of Scots pine sapwood. Holzforschung 2016, 70, 261-266. [CrossRef]

29. Harju, A.M.; Venäläinen, M.; Anttonen, S.; Viitanen, H.; Kainulainen, P.; Saranpää, P.; Vapaavuori, E. Chemical factors affecting the brown-rot decay resistance of Scots pine heartwood. Trees 2003, 17, 263-268. [CrossRef]

30. Venäläinen, M.; Harju, A.M.; Kainulainen, P.; Viitanen, H.; Nikulainen, H. Variation in the decay resistance and its relationship with other wood characteristics in old Scots pines. Ann. For. Sci. 2003, 60, 409-417. [CrossRef]

31. Celimene, C.C.; Micales, J.A.; Ferge, L.; Young, R.A. Efficacy of pinosylvins against white-rot and brown-rot fungi. Holzforschung 1999, 53, 491-497. [CrossRef]

32. Wijayanto, A.; Dumarçay, S.; Gérardin-Charbonnier, C.; Sari, R.K.; Syafii, W.; Gérardin, P. Phenolic and lipophilic extractives in Pinus merkusii Jungh. et de Vries knots and stemwood. Ind. Crops. Prod. 2015, 69, 466-471. [CrossRef]

33. Seppänen, S.K.; Syrjälä, L.; von Weissenberg, K.; Teeri, T.H.; Paajanen, L.; Pappinen, A. Antifungal activity of stilbenes in in vitro bioassays and in transgenic Populus expressing a gene encoding pinosylvin synthase. Plant. Cell. Rep. 2004, 22, 584-593. [CrossRef]

34. Vítková, M.; Müllerová, J.; Sádlo, J.; Pergl, J.; Pyšek, P. Black locust (Robinia pseudoacacia) beloved and despised: A story of an invasive tree in Central Europe. For. Ecol. Manage. 2017, 384, 287-302. [CrossRef] 
35. Bahor, B.; Klopcic, M. Black locust (Robinia pseudoacacia L.) in Bela krajina: Distribution, growth, regeneration and management. Acta Silvae Ligni 2019, 120, 13-28. [CrossRef]

36. Torelli, N. Robinija (Robinia pseudoacacia L.) in njen les. Les 2003, 54, 6-10.

37. De Filippis, L.; Magel, E. Identification of biochemical differences between the sapwood and transition zone in Robinia pseudoacacia L. by differential display of proteins. Holzforschung 2012, 66, 543-549. [CrossRef]

38. Bostyn, S.; Destandau, E.; Charpentier, J.P.; Serrano, V.; Seigneuret, J.M.; Breton, C. Optimization and kinetic modelling of robinetin and dihydrorobinetin extraction from Robinia pseudoacacia wood. Ind. Crops. Prod. 2018, 126, 22-30. [CrossRef]

39. Meszaros, E.; Jakab, E.; Varhegyi, G. TG/MS, Py-GOMS and THM-GIC/MS study of the composition and thermal behavior of extractive components of Robinia pseudoacacia. J. Anal. Appl. Pyrolysis 2007, 79, 61-70. [CrossRef]

40. Sanz, M.; de Simon, B.F.; Esteruelas, E.; Munoz, A.M.; Cadahia, E.; Hernandez, T.; Estrella, I.; Pinto, E. Effect of toasting intensity at cooperage on phenolic compounds in acacia (Robinia pseudoacacia) heartwood. J. Agric. Food Chem. 2011, 59, 3135-3145. [CrossRef]

41. Sergent, T.; Kohnen, S.; Jourez, B.; Beauve, C.; Schneider, Y.J.; Vincke, C. Characterization of black locust (Robinia pseudoacacia L.) heartwood extractives: Identification of resveratrol and piceatannol. Wood Sci. Technol. 2014, 48, 1005-1017. [CrossRef]

42. Magel, E.; Jayallemand, C.; Ziegler, H. Formation of heartwood substances in the stemwood of Robinia pseudoacacia L. II. Distribution of nonstructural carbohydrates and wood extractives across the trunk. Trees 1994, 8, 165-171. [CrossRef]

43. Vek, V.; Vivod, B.; Poljanšek, I.; Oven, P. Vsebnost ekstraktivov v skorji in lesu robinije (Robinia pseudoacacia L.)/Content of extractives in bark and wood of black locust (Robinia pseudoacacia L.). Acta Silvae Ligni 2019, 119, 13-25. [CrossRef]

44. Smith, A.L.; Campbell, C.L.; Walker, D.B.; Hanover, J.W. Extracts from black locust as wood preservatives: Extraction of decay resistance from black locust heartwood. Holzforschung 1989, 43, 293-296. [CrossRef]

45. Sablik, P.; Giagli, K.; Paril, P.; Baar, J.; Rademacher, P. Impact of extractive chemical compounds from durable wood species on fungal decay after impregnation of nondurable wood species. Eur. J. Wood Wood Prod. 2016, 74, 231-236. [CrossRef]

46. Rademacher, P.; Rousek, R.; Fodor, F.; Baar, J.; Koch, G.; Németh, R.; Pařil, P.; Paschová, Z.; Sablík, P.; Paul, D.; et al. Robinia Wood Research-New innovations for a traditional material. In Proceedings of the Eco-Efficient Resource Wood with Special Focus on Hardwoods, Hardwood Conference, Sopron, Hungary, 8-9 September 2016; pp. 80-108.

47. Hosseinihashemi, S.K.; HosseinAshrafi, S.K.; Goldeh, A.J.; Salem, M.Z.M. Antifungal and antioxidant activities of heartwood, bark, and leaf extracts of Robinia pseudoacacia. BioResources 2016, 11, 1634-1646. [CrossRef]

48. Schultz, T.P.; Nicholas, D.D. Naturally durable heartwood: Evidence for a proposed dual defensive function of the extractives. Phytochemisrty 2000, 54, 47-52. [CrossRef]

49. Hsu, F.L.; Chen, P.S.; Chang, H.T.; Chang, S.T. Effects of alkyl chain length of gallates on their antifungal property and potency as an environmentally benign preservative against wood-decay fungi. Int. Biodeterior. Biodegrad. 2009, 63, 543-547. [CrossRef]

50. Chen, P.S.; Chen, Y.H.; Yeh, T.F.; Chang, S.T. Mechanism of decay resistance of heartwood extracts from Acacia confusa against the brown-rot fungus Laetiporus sulphureus. Wood Sci. Technol. 2014, 48, 451-465. [CrossRef]

51. Schultz, T.P.; Harms, W.B.; Fisher, T.H.; McMurtrey, K.D.; Minn, J.; Nicholas, D.D. Durability of angiosperm heartwood: The importance of extractives. Holzforschung 1995, 49, 29-34. [CrossRef]

52. Schultz, T.P.; Nicholas, D.D.; Prewitt, M.L. Environmentally-benign wood preservatives based on an organic biocide: Antioxidant combination: Ground-contact efficacy ratings and BHT depletion after four years of exposure. Holzforschung 2004, 58, 300-304. [CrossRef]

53. Humar, M.; Petrič, M.; Pohleven, F. Changes of the $\mathrm{pH}$ value of impregnated wood during exposure to wood-rotting fungi. Holz Roh Werkst. 2001, 59, 288-293. [CrossRef]

54. Schmidt, O. Wood and Tree Fungi; Biology, Damage, Protection, and Use; Springer: Berlin/Heidelberg, Germany, 2006; p. 334. 
55. Green, F.; Clausen, C. Copper tolerance of brown-rot fungi: Oxalic acid production in southern pine treated with arsenic-free preservatives. Int. Biodeterior. Biodegrad. 2005, 56, 75-79. [CrossRef]

56. Humar, M.; Lesar, B. Fungicidal properties of individual components of copper-ethanolamine-based wood preservatives. Int. Biodeterior. Biodegrad. 2008, 62, 46-50. [CrossRef]

57. Vek, V. Application of Pinewood Extractives for Wood Preservation; Final Project Report; Republic of Slovenia, Ministry of Education, Science and Sport: Ljubljana, Slovenia, 2015.

58. Vek, V.; Poljanšek, I.; Oven, P. Variability in content of hydrophilic extractives and individual phenolic compounds in black locust stem. Eur. J. Wood Wood Prod. 2020, 78, 501-511. [CrossRef]

59. Willför, S.; Reunanen, M.; Eklund, P.; Sjoholm, R.; Kronberg, L.; Fardim, P.; Pietarinen, S.; Holmbom, B. Oligolignans in Norway spruce and Scots pine knots and Norway spruce stemwood. Holzforschung 2004, 58, 345-354. [CrossRef]

60. Dünisch, O.; Richter, H.G.; Koch, G. Wood properties of juvenile and mature heartwood in Robinia pseudoacacia L. Wood Sci. Technol. 2010, 44, 301-313. [CrossRef]

61. Vek, V. Extractives in Wounded Wood and Knots of Common Beech (Fagus sylvatica L.). Ph.D. Thesis, University of Ljubljana, Ljubljana, Slovenia, 2013; p. 162.

62. Vek, V.; Poljanšek, I.; Oven, P. Efficiency of three conventional methods for extraction of dihydrorobinetin and robinetin from wood of black locust. Eur. J. Wood Wood Prod. 2019, 77, 891-901. [CrossRef]

63. Singleton, V.L.; Rossi, J.A., Jr. Colorimetry of total phenolics with phosphomolybdic-phosphotungstic acid reagents. Am. J. Enol. Vitic. 1965, 16, 144-158.

64. Scalbert, A.; Monties, B.; Janin, G. Tannins in wood: Comparison of different estimation methods. J. Agric. Food Chem. 1989, 37, 1324-1329. [CrossRef]

65. Pearce, R.B. Antimicrobial defences in the wood of living trees. New Phytol. 1996, 132, 203-233. [CrossRef]

66. Raspor, P.; Smole-Možina, S.; Podjavoršek, J.; Pohleven, F.; Gogala, N.; Nekrep, F.V.; Rogelj, I.; Hacin, J. Culture collection of industrial microorganisms (ZIM). Biotech. Fac. Food Sci. Technol. Dept. 1995, 65, 65-72.

67. Humar, M.; Pohleven, F. Experiences with non-standard test methods for estimation of fungicidal properties and mode of fungicidal action (Experienţe în utilizarea unor metode de testare nestandardizate de evaluare a proprietâţilor fungicidelor şi a modului lor de acţiune). Pro Ligno 2007, 3, 17-25.

68. Zimmer, K.; Melcher, E. A screening study on extractive content and composition of Scots pine heartwood of three stands with close proximity and their resistance against basidiomycetes. Int. Wood Prod. J. 2017, 8, 45-49. [CrossRef]

69. Humar, M.; Thaler, N. Performance of copper treated utility poles and posts used in service for several years. Int. Biodeterior. Biodegrad. 2017, 116, 219-226. [CrossRef]

70. Pietrzak, W.; Nowak, R.; Olech, M. Effect of extraction method on phenolic content and antioxidant activity of mistletoe extracts from Viscum album subsp. abietis. Chem. Pap. 2014, 68, 976-982. [CrossRef]

71. Barros, L.; Baptista, P.; Ferreira, I.C.F.R. Effect of Lactarius piperatus fruiting body maturity stage on antioxidant activity measured by several biochemical assays. Food Chem. Toxicol. 2007, 45, 1731-1737. [CrossRef]

72. Benković, E.T.; Žigon, D.; Mihailović, V.; Petelinc, T.; Jamnik, P.; Kreft, S. Identification, in vitro and in vivo antioxidant activity, and gastrointestinal stability of lignans from silver fir (Abies alba) wood extract. J. Wood Chem. Technol. 2017, 467-477. [CrossRef]

73. Siau, J.F. Wood: Influence of Moisture on Physical Properties; Polytechnic Institute and State University: Blacksburg, VA, USA, 1995; pp. 39-63.

74. Fang, W.; Hemming, J.; Reunanen, M.; Eklund, P.; Conde, E.; Poljanšek, I.; Oven, P.; Willför, S. Evaluation of selective extraction methods for recovery of polyphenols from pine. Holzforschung 2013, 67, 843-851. [CrossRef]

75. Willför, S.; Hemming, J.; Reunanen, M.; Eckerman, C.; Holmbom, B. Lignans and lipophilic extractives in Norway spruce knots and stemwood. Holzforschung 2003, 57, 27-36. [CrossRef]

76. Willför, S.; Hemming, J.; Reunanen, M.; Holmbom, B. Phenolic and lipophilic extractives in Scots pine knots and stemwood. Holzforschung 2003, 57, 359-372. [CrossRef]

77. Lekounougou, S.; Mounguengui, S.; Dumarçay, S.; Rose, C.; Courty, P.E.; Garbaye, J.; Gérardin, P.; Jacquot, J.P.; Gelhaye, E. Initial stages of Fagus sylvatica wood colonization by the white-rot basidiomycete Trametes versicolor: Enzymatic characterization. Int. Biodeterior. Biodegrad. 2008, 61, 287-293. [CrossRef] 
78. Schultz, T.P.; Nicholas, D.D. Development of environmentally-benign wood preservatives based on the combination of organic biocides with antioxidants and metal chelators. Phytochemistry 2002, 61, 555-560. [CrossRef]

79. Ioannidis, K.; Melliou, E.; Alizoti, P.; Magiatis, P. Identification of black pine (Pinus nigra Arn.) heartwood as a rich source of bioactive stilbenes by qNMR. J. Sci. Food. Agric. 2017, 97, 1708-1716. [CrossRef] [PubMed]

80. Arantes, V.; Jellison, J.; Goodell, B. Peculiarities of brown-rot fungi and biochemical Fenton reaction with regard to their potential as a model for bioprocessing biomass. Appl. Microbiol. Biotechnol. 2012, 94, 323-338. [CrossRef]

81. Reinprecht, L. Wood Deterioration, Protection and Maintenance; John Wiley \& Sons: Hoboken, NJ, USA, 2016; p. 376.

82. Backa, S.; Gierer, J.; Reitberger, T.; Nilsson, T. Hydroxyl radical activity associated with the growth of white-rot fungi. Holzforschung 1993, 47, 181-187. [CrossRef]

(C) 2020 by the authors. Licensee MDPI, Basel, Switzerland. This article is an open access article distributed under the terms and conditions of the Creative Commons Attribution (CC BY) license (http://creativecommons.org/licenses/by/4.0/). 